\title{
IETS OVER DE MUTILATIE DER TANDEN BIJ DE VOLKEN VAN DEN INDISCHEN ARCHIPEL.
}

\author{
OPMERKINGEN NAAR AANLEIDING VAN UHLE'S "UEBER DIE ETHNOLO- \\ GISCHE BEDEUTUNG DER MALAIISCHEN ZAHNFEILUNG". \\ DOOR
}

DR. G. A. W I L K E N.

Het was eene gelukkige gedachte van den Directeur van het Ethnographisch Museum te Dresden, Dr. Meyer, om aan zijne vrienden en andere personen in Indië eene reeks van vragen te zenden betreffende de tandvijling ${ }^{1}$. Hierop zijn verschillende antwoorden ingekomen, bijna allen afkomstig van Ambtenaren bij het Binnenlandsch Bestuur. Het dus bijeengebrachte materiaal is door Dr. Meyer ter bewerking in handen gesteld van zijnen Assistent, den bij de lezers van dit tijdschrift bekenden Dr. Max Uhle, en zoo is de verhandeling ontstaan, waarvan de titel aan het hoofd van dit opstel afgeschreven is. Door deze verhandeling heeft Dr. Uhle de belangstellenden in de ethnographie onzer Aziatische Bezittingen opnieuw aan zich verplicht. Te betreuren is het, dat, gelijk de schrijver opmerkt, in de, op de vragenreeks ingekomen, antwoorden de verschillende deelen van den Archipel zoo ongelijkmatig vertegenwoordigd zijn ${ }^{2}$. Door gebruikmaking van andere, in de laatste

1 De vragenreeks werd opgesteld naar aanleiding van de verhandeling van Von Ihering, Die künstliche Deformirung der Zähne, Zeitschrift für Ethnologie, jaarg. 1882 (dl. XIV), blz. 213 vv., waarin op blz. 240-260 speciaal over de tandvijling in den Indischen Archipel gehandeld wordt. Zelf heeft Dr. Meyer twee kleinere opstellen over dit onderwerp geschreven, namelijk: Notizen über das Feilen der Zähne bei den Völkern des Ostindischen Archipels, Mittheilungen der anthropologischen Gesellschaft in Wien, dl. VII, blz. 214 vv., en Das Feilen der Zähne bei den Bewohnern des Ostindischen Archipels, speziell bei den Javanen, Ausland, jaarg. 1883, blz. 401 vv. In dit laatste stuk is ook de vragenreeks afgedrukt.

2 Van de ingekomen antwoorden zijn namelijk 11 af komstig van Sumatra (en wel 1 van Atjeh, 1 van Sumatra's Oostkust, 8 van de Padangsche Bovenlanden, 1 van Bengkoelen), 1 van Nias, 1 van Bangka, 7 van Java ( 1 van de Preanger Regentschappen, I van Krawang, 2 van Tegal, 1 van Bagelen, 1 van Kedoe 1 van Japara), 1 van Zuid-Celebes, 1 van Saleijer. 
jaren gepubliceerde, stukken, voornamelijk van de Heeren Riedel, Kreemer, Neumann, Hagen en Grabowsky $\mathbf{3}$, heeft echter Dr. Uhle zooveel mogelijk getracht, een eenigszins volledig beeld van het gebruik der tandvijling bij de Indonesische volken te ontwerpen. Het is mijo doel in de volgende bladrijden de aandacht te vestigen op eenige der voornaamste resultaten waartoe de schrijver gekomen is, ook om naar aanleiding daarvan enkele opmerkingen in het midden te brengen.

Het gebruik van de tandvịling komt bij tal van stammen in den Indischen Archipel voor. Dr. Uhle wijst er echter op, dat er enkele streken zijn, waarvan men niet met zekerheid weet, of daar de gewoonte bestaat. "So", zegt hij onder anderen (blz. 3), "ist mir keine Nachricht über Zahndeformation von den kleinen SundaInseln (ausser Bali) bekannt, obwohl wegen der leichten Durehdringlichkeit dieser Inseln nicht daran zu zweifeln ist, dass die Sitte da allgemein ist". Zeer zeker is deze onderstelling juist. Bij de Rotineezen bij voorbeeld behoort het vijlen van de tanden der bruid tot de plechtigheden der huwelijksvoltrekking ${ }^{4}$, terwijl het van de Soembaneezen heet, dat bij hen van mannen zoowel als van vrouwen de tanden kort afgeslepen worden, bij velen tot aan het tandvleesch 5. Het gebruik vinden wij ook vermeld van de Savoeneezen. "When the symptoms of puberty appear, the girls are subjected to having their teeth filed", deelt de Heer Riedel mede ${ }^{6}$. Volgens Salomon Müller geschiedt dit eveneens tot aan het tandvleesch 7 .

3 Riedel, De sluik- en kroesharige rassen tusschen Selebes en Papua, passim; Kreemer, Hoe de Javanen hunne tanden verzorgen, Mededeelingen v. w. h. Nederl. Zend. Gen., dl. XXV, blz. 197 vv.; Neumaun, Het Pane- en Bila-Stroomgebied, Tijdschr. v. h. Nederl. Aardr. Gen., 2e serie, dl. III, bl. 460 vv.; Hagen, Die künstlichen Verunstaltungen des Körpers bei den Batta, Zeitschrift für Ethnologie, jaarg. 1884 (dl. XVI), blz. 219 vv.; Grabowsky, Das Feilen und Färben der Zähne bei den Bewohnern Südost-Borneos, speziell den Malaien der Distrikte Batang-Alai und Laboean-Amas, Ausland, jaarg. 1884, blz. 125-126.

4 Heymering, Zeden en gewoonten van het eiland Roti, Tijdschr. v. Nederl. Indië, jaarg. 1843, dl. II, blz. 583 vlg.

${ }^{5}$ Roos, Bijdrage tot de kennis van taal, land en volk van Soemba, Verhandelingen v. h. Bat. Gen. v. K. en W., dl. XXXVI, blz. 69. Zie ook: Beschrijving van het eiland Soemba, Tijdschr. v. Nederl. Indië, jaarg. 1855, dl. I, blz. 289 ,

${ }^{6}$ Riedel, The Sawu Group, Revue coloniale internationale, jaarg. 1885, dl. I, blz. 309 .

7 Sal. Müller, Reizen in den Indischen Archipel, dl. II, blz. 279. Zie ook: Bijdragen tot de kennis van het eiland Timor en Onderhoorigheden, Tijdschr. v. Nederl. Indië, jaarg. 1849 , dl. II, blz. 312. 
Ook de mannen laten hunne tanden vijlen 7a. Bij de Timoreezen "wird das Feilen der Zähne mit Steinen oder mit dem Bambusa longinodis, gegen den Eintritt der Pubertät von alten Männern und Frauen vorgenommen" 8 . Op de Solor-eilanden komt het vijlen der tanden voor, hoewel dit niet door allen geschiedt 9. Dat eindelijk bij de stammen, die het Zuidelijk gedeelte van Midden-Flores bewonen, het gebruik evenzeer bestaat, blijkt uit een bericht van Dr. Riedel. "The sharpening of the teeth", aldus lezen wij in zijne beschrijving van genoemde landstreek, "does not take place till marriage is contemplated" 10. Wij zien dus dat op de Kleine Soendaeilanden, althans op die welke de Residentie Timor vormen, de tandvijling vrij algemeen wordt aangetroffen.

Belangrijk vooral zijn de mededeelingen van Dr. Uhle over de verschillende wijzen waarop de tandvijling plaats heeft. In zijne verhandeling "Die künstliche Deformirung der Zähne", neemt Von Thering vier hoofdvormen voor den Indischen Archipel aan, namelijk: "10 Flächenfeilung: starke Abfeilung der Vorderfläche des Zahnes so zwar, dass eine sattelförmige Vertiefung sich auf der vorderen Zahnfläche befindet; 20 Herausfeilung eines dreieckigen, erhaben stehen bleibenden Mittelfeldes (Relieffeilung) mit Abschleifung des unteren Randes; 30 Herausfeilung eines dreieckigen Mittelfeldes (Relieffeilung) und Spitzfeilung des unteren Randes; 40 Zuspitzung durch Feilung, ohne Relieffeilung der Zahnvorderseite". Volgens Uhle echter "findet sich nicht nur als Gegensatz Gerad- und Spitzfeilung des unteren Zahnrandes, sondern Gerad-, Rund- und Spitzfeilung. Es findet sich Spitzfeilung mit Relieffeilung, wie Spitzfeilung ohne Relieffeilung. Es findet sich Abfeilung der vorderen Fläche, aber auch Unterlassung der vorderen Abfeilung, z. B. wenn der Zahn blos kurz abgenommen (besonders abgesägt) wird. Es finden sich neben gerader oder concaver Abfeilung der Vorderseite auch mannigfache convexe Abfeilungen der Vorderseite, welche unter allen Umständen schwer alle mit in Herrn v. Thering's 1 Classe, Flächenfeilung, zu bringen sein würden; zacken-, rinnenförmige

7a Zie de in de voorgaande noot geciteerde Bijdragen tot de kennis van het eiland Timor en Onderhoorigheden, t. a. p.

8 Riedel, Die Landschaft Dawan oder West-Timor, Deutsche geographische Blätter, dl. X, blz. 284.

$\checkmark$ Zie de in noot 7 geciteerde Bijdragen tot de kennis van het eiland Timor en Onderhoorigheden, blz. 309.

10 Riedel, The island of Flores or Pulau Bunga, Revue coloniale internationale, jaarg. 1886, dl. I, blz. 71 . 
Ausfeilungen der Vorderseite, welche in Herrn von Thering's System alle unverwendet geblieben sind, und die Aufstellung mehrerer Classen noch zum Mindesten erfordert haben würden" (blz. 8-9). Uhle neemt dan ook zeventien vormen van tandvijling bij de Indonesische volken aan. Wij zullen die allen hier niet nagaan, daar dit ons te ver voeren zou. Enkele opmerkingen slechts mogen hier eene plaats vinden, naar aanleiding van hetgeen de schrijver over de spitsvijling zegt.

De spitsvijling kan met of zonder reliefvijling plaats hebben. De eerste vorm, spitsvijling met reliefvijling, die op Java in verschillende residenties (Krawang, Banjoemas, Bagelen, Jogjakarta, Soerakarta, Madioen, Kediri) wordt aangetroffen, komt hierop neer, dat de tanden aan den onderkant puntig gemaakt worden, terwijl zij aan het voorvlak zoodanig worden bewerkt, dat, door eene gedeeltelijke verwijdering van het glazuursel, een ruitvormig relief ontstaat. Dit, door het overgebleven glazuursel gevormde, relief heet widji-timun $=$ komkommerpit, hoewel deze naam wel eens op de geheele vijling toegepast wordt 10a. Meer verbreid is de eenvoudige spitsvijling, zonder reliefvijling. Hierbij zijn de tanden hetzij alleen aan den onderkant puntig gemaakt, zoodat het gebit zich als eene zaag voordoet, hetzij over hunne geheele lengte aan beide zijden naar beneden schuins afgevijld in de gedaante van eenen driehoek. Deze wijze van vijling komt, behalve bij eenige Negrito-stammen van de Philippijnen 11 en bij de Papuwa's van Oetanata op de Zuidwestkust van Nieuw-Guinea 11a, voor bij de Bagobo's van het

\footnotetext{
10a Zie hierbeneden blz. 494. - Vergelijk ook noot $57_{\mathrm{b}}$, waaruit blijkt, dat de bewerking van de tanden met het relief widji-timun ook wel eens zonder spitsvijling plaats heeft.

11 Virchow, Ueber alte und neue Schädel von den Philippinen, opgenomen in het werk van Jagor, Reisen in den Philippinen, blz. 374-375, en de daarbij behoorende PI. II , fig. 4 en 5. Zie ook : Blumentritt, Ethnographie der Philippinen, blz. 6.

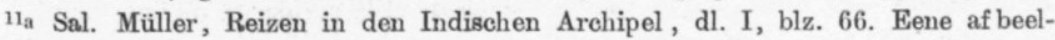
ding, van zulk een Papuwa met spits gevijlde tanden vindt men bij: Temminck, Verhandelingen over de Natuurkundige geschiedenis der Nederlandsche Overzeesche Berittingen, Afd. Land- en Volkenkunde, Pl. VI, fig. 4. - Overigens komt de tandvijling op Nieuw-Guinea niet voor, ontbreekt zij onder anderen geheel en al op de Noordkust, in de omstreken bij voorbeeld van de Geelvinksbaai. Bij de Papuwa's echter die de Papoesche eilanden, dat zijn de eilanden tusschen Nieuw-Guinea en Halmahera, bewonen, wordt het gebruik gevonden, ofschoon niet algemeen. Gerland (Waitz, Anthropologie der Naturvölker, dl. VI, blz. 570) en, in navolging van hem, Von Ihering (Die künstliche Deformirung der Zähne, blz. 257), ook, naar het schijnt, Uhle (blz. 5), doen het voorkomen alsof hier, bepaaldelijk op Waigeoe, de spitsvijling bestond. Eerstgenoemde citeert daarvoor het werk van De Freyeinet, Voyage sutour du monde, dl. II, blz. 48. Intussehen is er hier volstrekt geen sprake van
} 
eiland Mindanao 12, verder bij de Sibnowans. een Dajakschen stam aan de Loendoe-rivier in Sarawak 13, op Sumatra bịj de Maleiers van het landschap XII Kota, het Zuidelijkst deel der Padangsche Bovenlanden, en bij de Redjangers van Lebong en die, welke in het aangrenzende deel van Bengkoelen gevestigd zijn 14, terwịl ook van Java, en wel van Japara, "brieflich garantirt wird, dass dort Spitzfeilung auch ohne Zufügung von Reliefs an der Zahnvorderseite vorkommt" (blz. 10). "Für andere Gebiete", aldus gaat Dr. Uhle voort, "für welche die Spitzfeilung früher wohl zeitweilig in Anspruch genommen wurde, wird sie unsicher, oder ist sie in neuerer Zeit widerlegt. So hatte Herr von Rosenberg angegeben, dass die Bewohner von Nias die Zähne spitz feilen. Gegenwärtig hat in einer brieflichen Mittheilung Herr Kleijer das Vorkommen jeder Art von Spitzfeilung auf Nias in Abrede gestellt. Damit werden auch die ähnlichen Nachrichten, dass in den Mentawei (Herr v. Rosenberg, Tijdschr. v. Ind. T. L. en Vk., I, S. 410) und Pageh Inseln (Blunt, Hardwicke und Hunter, Reisen durch Ostindien, 1808) die Zähne spitz zu feilen üblich sei, wieder mehr als fragwürdig".

Naar aanleiding van het voorgaande hebben wij hier een paar opmerkingen te maken. Volledigheidshalve wénschen wij eerstens er op te wijzen, dat, hoewel de spitsvijling heden ten dage, behalve bij de Bagobo's, bij de Maleische stammen vau de Philippijnen niet meer schijnt voor te komen, dit voorheen anders was. In de beschrijving toch van deze eilanden, vervaardigd door een Spaansch geestelijke van het begin der 17e eeuw, opgenomen in

zulk eene vijling. "Chez les Papous (van Waigeoe)", aldus lezen wij ter aangehaalder plaatse, "on voit en général les dents fort belles; un petit nombre les ont noires et limées à la manière des Guébéens". Van de bewoners van Gebe nu heet het (O. e, blz. 8): "Ils ont des dents noircies par l'usage du bétel; les incisives supérieures sont concaves en devant, par suite d'une opération faite avec la lime à un certain âge; ear les enfans sont remarquables par la blancheur et la régularité de leur denture".

12 Uhle, die naar het werk van Montano, Rapport sur une mission aux lles Philippines et en Malaisie, verwijst, waar, Pl. XXX, de bovenkaak van eenen Bagobo-schedel, met spits gevijlde tanden, afgebeeld is, had hiervoor nog het opstel van Schadenberg, Die Bewohner von Süd-Mindanao und der Insel Samal (Zeitschrift für Ethnologie, jaarg. 1885, blz. 8 vv.), kumnen eiteeren, waar het (blz. 9) van de Bagobo's heet, dat sommigen de tanden "spitz zufeilen wie Haifischzähne".

13 Keppel, Expedition to Borneo, dl. I, blz. 59. - De Loendoe is een riviertje, dat niet ver ten Oosten van Kaap Datoe in zee valt.

14 Van Hasselt, Volksbeschrijving van Midden-Sumatra, blz. 7, en Ethnographisohe atlas van Midden-Sumatra, blz. 9 en Pl. XXIV, fig. 4. Voor Bengkoelen eiteert Dr. Uhle het uit dit gewest ontvangen antwoord op de vragenreeks. Zie overigens: Marsden, History of Sumatra, blz. 52. 
het bekende werk van Thévenot "Relations de divers voyages cvrievx" heet het: "Pour ce qui est des dents, elles (de vrouwen) imitent en tout les hommes: ils se les liment dès leur plus tendre ieunesse, les vns les rendent par là esgales, les autres les affilent en pointes, en leur donnant la figure d'vne sie" 14a. Ontegenzeggelijk heeft dit bericht betrekking, niet op de Negritos, gelijk onder anderen Prof. Virchow dit schijnt te meenen ${ }^{15}$, doch op de Maleische stammen, misschien wel de Tagala's en Bisaya's, over wie de mededeelingen van den geestelijke hoofdzakelijk loopen. - Dan verdient het opmerking dat er ook eene mededeeling van den Heer Poensen is, waaruit zou kunnen worden opgemaakt, dat op Java, speciaal misschien in Kediri, waar de schrijver gevestigd is, de eenvoudige spitsvijling bestaat. "Nu eens", aldus lezen wij, "worden de tanden gedeeltelijk, dan weer tot op het tandvleesch weggenomen; ook wel laat men ze, om ze heel mooi te maken, als een zaagje met scherpe punten afbeitelen" 15a. $\mathrm{Er}$ is onzes inziens geen enkele grond om an te nemen, dat hier eene spitsvijling met reliefvijling bedoeld is. - In de derde plaats moet worden aangeteekend, dat de spitsvijling in Sarawak niet, gelijk Dr. Uhle dit doet voorkomen, alleen tot de Sibnowans beperkt is, doch bij meer stammen voorkomt. Keppel, op wien Uhle zich beroept, zegt toch, op eene andere plaats van zijn werk "Expedition to Borneo", in het algemeen van de Land-Dajaks sprekende: "The teeth of the young people are sometimes filed to a point" 15b. Zoo vermeldt ook Charles Brooke, in zijn "Ten years in Sarawak", dat bij de vrouwen van de Zee-Dajaks "the teeth are stained black and filed to a point" 15c. Een dergelijk bericht vinden wij eveneens in Boyle's "Adventures among the Dyaks of Borneo". Sommigen, zegt deze schrijver, meer in het bijzonder van de ZeeDajaks, die langs de Batang Ioepar en haren linkertak, de Oendoep, wonen, vijlen de tanden "to a point as sharp as a needle" ${ }^{15 d}$. Uit al deze, zeker volkomen 'betrouwbare, mededeelingen blijkt dus dat de spitsvijling algemeener in Sarawak wordt aangetroffen, dan Uhle dit schijnt te meenen. Zelfs bij de Maleiers, die hier, bepaaldelijk

14a Thévenot, O. c., dl. II, blz. 4.

15 Zie zijne in noot 11 geciteerde verhandeling, blz. 375 .

15a Poensen, Iets over de kleeding der Javanen, Mededeelingen v. w. h. Nederl.

Zend. Gen., dl. XX, blz. 293.

15b Keppel, O. c., dl. II, blz. 184.

${ }^{15} \mathrm{c}$ Charles Brooke, Ten years in Sarawak, dl. I, bla. 67.

15d Boyle, 0. c., blz. 228.

5e Volgr. III. 
dan langs de kusten, gevestigd zijn, doet zich deze vijling voor 15e. Eindelijk hebben wij op te komen tegen de uitspraak van Dr. Uhle in de vraag, of op de Mentawei-eilanden de spitsvijling bestaat. Ik begin met de opmerking dat Von Rosenberg, voor zoover althans ik dit heb kunnen nagaan, nergens van de Niasers gezegd heeft, dat zij de tanden spits vijlen. Integendeel leest men in zijne bekende verhandeling: "De bovensnijtanden worden bij den Niaser evenals bij den Maleier voor een gedeelte afgevijld" 16. Verder is het niet duidelijk, welken grond Dr. Uhle heeft, om, nu de spitsvijling op Nias niet gevonden wordt, ook de berichten omtrent het voorkomen daarvan op de Mentaweieilanden in twijfel te trekken. Immers de bewoners van deze eilanden zijn, hetgeen Uhle evengoed als ieder ander weet, niet het minst aan de Niasers verwant, zoodat het zeer wel mogelijk is dat zij de spitsvijling hebben, in weerwil dat die bij de laatstgenoemden onbekend is. De verschillende berichten, die wij daaromtrent bezitten, sluiten dan ook allen twijfel uit. Behalve door Von Rosenberg in zijne, door Dr. Uhle genoemde, verhandeling $\mathbf{1 7}$, vinden wij toch de spitsvijling van de Mentawei- en de Pageh-eilanders vermeld door Crisp, Hinlopen en Severijn, en, zeer vitvoerig, door Mess 18. Laatstgenoemde schrijver deelt ook de legende mede omtrent den oorsprong van het gebruik. De Mentawei-eilanders zouden namelijk, volgens eene Maleische overlevering, afstammen van Jambang Djaja, radja van Soengei-Ngiang, dat ergens op Sumatra, vermoedelijk in de Djambische Bovenlanden, gelegen zou zijn. Gezegde Jambang Djaja, aldus gaat de Heer Mess voort, was een groot en beroemd vorst. Evenwel nam zulks niet weg, dat men hem, een oogenblik

15e Boyle, t. a. p.

16 Von Rosenberg, Het eiland Nias, Verhandelingen v. h. Bat. Gen. v. K. en W., dl. XXX, blz. 27. Ook in zijn opstel "Een ethnographisch probleem" (opgenomen in de "Etudes archéologiques, linguistiques et historiques, dédiées a Mr. le Dr. C. Leemans, à l'occasion du cinquantième anniversaire de sa nomination aux fonctions de Directeur du Musée archéologique des Pays-Bas", blz. 164 vv.), stelt de Heer Von Rosenberg, waar hij eene parallel trekt tusschen de bewoners van de Mentaweieilanden en de Niasers, bepaaldelijk de spitsvijling van de eerstgenoemden tegenover de gewone vijling van de laatsten.

17 Het door Dr. Uhle geciteerde werk van Blunt, Hardwicke en Hunter heb ik niet kunnen raadplegen.

18 Crisp, An account of the inhabitants of the Poggy, or Nassau Islands, Asiatic Researches, dl. VI, blz. 83; Hinlopen en Severijn, Verslag van een onderzoek der Poggi-eilanden, Tijdschr. v. Ind. T. L. en Vk., dl. III, blz. 324 ; Mess, De Mentawei-eilanden, Tijdschr. v. Ind. T. L. en Vk., dl. XXVI, blz. 65 en 75. 
voor dat hij in het huwelijk zou treden, zijne bruid met geweld ontvoerde. Dit waagstuk werd, op last en ten behoeve van den radja van Menangkabau, uitgevoerd door zekeren Tjindur Mata. Om deze reden werden alle betrekkingen tusschen de beide rijken afgebroken, en ontstond er eene verwijdering tusschen de bewoners van Soengei-Ngiang en de Menangkabauërs. Ten einde de afscheiding zooveel mogelijk te bevorderen, vaardigde Jambang Djaja zelfs eene wet uit, waarbij aan zijne onderdanen, zoowel mannen als vrouwen, onder bedreiging van zware straffen, bevolen werd, zich de tanden in den mond spits te laten vijlen gelijk de punten van eene sero 19 , waarom de op die wijze gevijlde tanden bij de Maleiers nog heden ten dage gigi tadjam bělat, tanden gespitst als eene bělat, heeten 19a. Later zouden de Soengei-Ngiangers meer naar de Westkust van Sumatra voortgedrongen en eindelijk naar de Mentawei-eilanden verhuisd zijn.

Ook omtrent het tijdstip, waarop de tandvijling plaats heeft, danken wij aan Dr. Uhle eene interessante mededeeling. Bekend is het dat de operatie in den regel geschiedt bij het intreden der puberteit of met het huwelijk 20. Volgens Dr. Uhle nu (en dit is voor ons, gelijk zeker voor de meesten, geheel nieuw) komt ook tandvijling bij sterfgevallen voor als teeken van rouw. Wij kunnen niet beter doen dan door hetgeen de schrijver daaromtrent zegt hier te laten volgen.

"Die Verstümmelung der Zähne als Zeichen der Trauer ", aldus heet het (blz. 6), "welche als etwas sehr Merkwürdiges bisher nur von Polynesien bekannt war, und dort unter der Form des Zähneausbrechens vorkommt, findet sich auch im Ostindischen Archipel bei malaiischen Völkern, hier aber in der abweichenden Form der Zahnabfeilung zur Trauer. Dieser eigenthümliche malaiische Gebrauch

19 De sero is eene soort van vaste fuik, bestaande uit een staketsel van bamboestokken, die, op plaatsen waar de visch de oevers druk bezoekt, vaak in eenige vademen waters, in den bodem zijn ingedreven, onderling stevig verbonden door idjoek-touw, en zoo gesteld dat zij, als het ware, een doolhof vormen, waaruit de visch, die er eenmaal is ingeraakt, den uitweg niet meer kan vinden.

19a De belat is eene soort van sero.

20 De tandvijling is in het laatste geval eene ceremonie van de huwelijksvoltrekking. In plaats van de werkelijke vijling, wordt er bij de Maleiers van den Riouw-Lingga-Archipel dan echter dikwijls alleen het zoogenaamde mělětak-batu verricht, hierin bestaande, dat de steen, waarmede de operatie moet geschieden, slechts even op de tanden der bruid wordt gezet; het afslijpen heeft dan na de voltrekking van den echt, naar goedvinden, plaats (Von de Wall-Van der Tuuk, Maleiseh woordenboek, i. v. batu). 
bildet ein merkwürdiges Beispiel dafür, wie oft noch sehr interessante, oder die interessantesten, Gebräuche selbst dann noch verborgen bleiben können, wenn man schon lange und durch die fast unendlich gekreuzten Beobachtungen der Berichterstatter das ganze wesentliche Bild eines Volkes fest vor sich gestellt zu haben scheint. - Herr Riedel bemerkt in seinem Aufsatze über die Sulanesen (Bijdragen tot de T. L. en Vk. v. Nederl. Indië, 4 e volgreeks, dl. X, blz. 405), nachdem er über die Art, wie die Zähne zur Zeit der Pubertät gefeilt werden, gesprochen, ganz beilüufig: "”Wenn Jemand Brüder oder Schwestern hat, ist es bobosi oder verboten, die untersten Zähne zu feilen " ". Dass es sich in dieser eigenthümlichen, nur zu leicht confus scheinenden Notiz um die correcte, zweifelsohne von dem geehrten Berichterstatter selbst nicht verstandene, darum doch glücklicherweise weder unterdrückte noch sonst verstümmelte Bezugnahme auf einen positiven Trauergebrauch (Abfeilen der Zähne zur Trauer) handelt, ist noch Niemandem aufgefallen, geht aber aus folgenden anderen Nachrichten, in welchen Feilung zur Trauer gleichfalls, nur deutlicher, aus dem Ostindischen Archipel bestätigt wird, hervor. In den Mittheilungen über die Zahnfeilung in Kedu durch Herrn De Bruijn Prince (brieflich) findet sich der Satz: " "Nur Personen, deren Vater und Mutter und ältere Schwestern oder Brüder alle gestorben sind, dürfen sich die Zühne des Unterkiefers schleifen lassen " ". In denen des Herrn Aeckerlin über die Zahnfeilung im Umkreis des Ortes Bengkulen (West Sumatra) findet sich der Satz: " " Seine Unterkiefer feilt nur Der, welcher keine Verwandten mehr hat"" . - - Auch in der Nachricht Herrn Riedel's handelte es sich also nicht un eine beiläufige Modalität, unter welcher Abfeilung der unteren Zähne bei der Pubertätsfeilung zu unterbleiben hat, sondern um das Verbot der unrechtzeitigen Vornahme eines regelrechten Trauergebrauchs, welcher in dem Abfeilen der unteren Zähne nach dem Tode naher Verwandten besteht. Dass blos nach dem Tode von Geschwistern und Brüdern die unteren Zähne abgefeilt werden, ist vielleicht in der die Sulanesen betreffenden Nachricht missverständlich. Denn man sieht nicht ein, welchen Vorzug Brüder und Geschwister z. B. vor den Eltern haben sollten, dass jener, und nicht dieser Tod mit, die Feilung zur Trauer nach sich zieht. In den Nachrichten von Kedu und Bengkulen ist das Hinscheiden aller näheren Verwandten für das Trauerabzeichen vorausgesetzt, und um etwas Aehnliches handelt es sich wohl auch nach dem Sinne in der Nachricht von den Sula Inseln". - Behalve in Kedoe, de 
Ommelanden van Bengkoelen en op de Soela-eilanden, schijnt, volgens een bericht van Saleijer, ook hier de tandvijling als teeken van rouw voor te komen. "Herr Schouten", aldus schrijft Dr. Uhle verder, "theilte brieflich von Saleijer mit, dass " "die Frauen sich (nach der 1. Zahnfeilung) im späteren Leben die Zähne auch noch feilen lassen, wenn sie Unglück trifft, als Todgeburt, baldiger Tod des Kindes nach der Geburt, auch wenn während der Verlobungszeit der Bräutigam stirbt. Das heisst balurappo 21. Das MehrmalsSchleifen hat nur bei Frauen statt" ". Principiell scheint diese letztere Nachricht zuzulassen, dass die Deformirung zur Trauer im Leben wiederholt vorgenommen wird, was nach den ersteren Nachrichten nicht so der Fall zu sein scheint". - Op drie of, met inbegrip van Saleijer, op vier punten van den Archipel wordt dus de tandvijling als teeken van rouw gevonden. Het is echter, volgens Dr. Uhle, aan te nemen, dat het gebruik meer verbreid is. "Je später die ersten Nachrichten über diese Sitte gekommen sind, je identischer dieselben lauten, und je schwerer zu beobachten die Sitte an und für sich ist, da mehr ein seelisches Motiv als eine sichtbare Form zu beobachten ist, desto wahrscheinlicher ist eine häufigere Verbreitung der Sitte, wenn auch die historische Bedeutung ihres Vorkommens im Archipel durch Nachweis ergiebigerer Verbreitung kaum noch erhöht werden kann".

Tot zoover Dr. Uhle. Ontegenzeggelijk is zijne mededeeling van groot gewicht. De vraag is echter, in hoeverre hij nit de geciteerde berichten te recht heeft opgemaakt, dat de tandvijling een rouwgebruik is. Immers uitdrukkelijk wordt dit nergens verklaard, en alleen gezegd, dat men de tanden, bepaaldelijk die van de onderkaak, eerst mag laten vijlen, nadat men zijne naaste bloedverwanten door den dood verloren heeft. Gaat het nu aan om, gelijk Dr. Uhle dit in het wezen der zaak gedaan heeft, zonder meer hier uit het post tot het propter te besluiten? Natuurlijk moet deze vraag ontkennend beantwoord worden. Evenwel willen wij dadelijk

21 Het woord balurappo beteekent "pinang-weduwnaar" of "pinang-weduwe", en wordt "gebezigd van hem of van haar, welke verloofd zijnde, dien band nog vóór het huwelijk, evenals een tot het sirih-kauwen aan stukken gebroken pinang-noot, door den dood verbroken ziet. Wie van de twee overblijft, heeft weinig kans meer om te trouwen. Het eenige middel, om dien vloek weg te nemen, bestat hierin, dat zulk een persoon naar een pinangboom gebracht, en daar met het hoofd tot drie keeren tegen aangeduwd wordt" (Matthes, Makassaarsch woordenboek, i. v. rappo). 
toegeven, dat er in de aangevoerde feiten eene aanwijzing gelegen is, dat, zoo nu niet meer, dan toch voorheen de tandvijling een rouwbedrijf moet zijn geweest. Dit laat zich naar analogie van een ander gebruik verklaren. Bij de Makassaren en Boegineezen namelijk plegen de vrouwen, gelijk dit ook bij andere stammen van den Indischen Archipel de gewoonte is $\mathbf{2 2}$, in den rouw het hoofd te omsluieren, mabowong, door over dit lichaamsdeel een doek te dragen. Vandaar dat het zeer verkeerd is, wanneer men niet in den rouw is, op die wijze bij iemand te komen. De vrouw, die zulks doet, loopt gevaar spoedig een sterfgeval te zullen veroorzaken in hare eigen familie of in die van degenen, aan wie zij het bezoek brengt 23. Het laat zich hooren, dat op analoge wijze, waar het gebruik bestaat de tanden als teeken van rouw voor de naaste bloedverwanten te vijlen, het een malum omen zou zijn, dit te doen als die bloedverwanten nog in leven waren, daar men daardoor hunnen dood verhaasten zou. Werkelijk vinden wij een bericht, hetwelk dit bevestigt. De Heer De Clercq zegt namelijk van de Alfoeren der Minahasa: "Het afvijlen der onderste tanden mag eerst geschieden na het overlijden der ouders. Dit vereischt eenige opheldering. In de Minahasa toch worden niet, zooals elders in den Indischen Archipel, de tanden afgevijld tot op gelijke hoogte met of even onder het tandvleesch, maar alleen de oneffenheden gelijk gemaakt, tot alle tanden even lang zijn. Uit een aesthetisch oogpunt wordt dit zeer hoog geschat en bijzonder op prijs gesteld. Wordt hiertoe vroeger overgegaan, dan zou het kind oorzaak kunnen zijn, dat een zijner ouders spoedig stierf. Is er evenwel één overleden, dan is het geoorloofd. Voor de bovenste tanden is het geheel onverschillig, welk tijdstip men daartoe kiest" 24. In de Minahasa is dus het vijlen van de tanden, ook van die der onderkaak, gelijk uit de geciteerde woorden blijkt, nu eenvoudig een middel tot verfraaiing. Toch mogen wij, op grond van het zooeven aangevoerde, aannemen, dat het voorheen als teeken van rouw geschiedde. Op die wijze behooren waarschijnlijk ook de door Dr. Uhle geciteerde berichten omtrent de bewoners van Kedoe, de Ommelanden van

22 Zie hierover mijne verhandeling: Ueber das Haaropfer und einige andere Trauergebräuche bei den Völkern Indonesiens, blz. 18 vv. (van den overdruk).

23 Matthes, Bijdragen tot de ethnologie van Zuid-Celebes, blz. 150-151. Zie ook mijne in de voorgaande noot geciteerde verhandeling, blz. 22 .

24 De Clereq, Iets over het bijgeloof in de Minahasa, Tijdschrift v. Nederl. Indië, jaarg. 1870 , dl. II, blz. 4. 
Bengkoelen, de Soela-eilanden en Saleijer te worden opgevat. Meer dan eene aanwijzing dat de tandvijling eenmaal bij hen een rouwgebruik is geweest, kunnen wij in die berichten niet zien. Misschien dat Dr. Uhle dit ook zoo bedoeld heeft; gezegd heeft hij het echter niet, noch veel minder aangetoond. Intusschen moeten wij hem dankbaar zijn, dat hij op het feit de aandacht heeft gevestigd. Mogen zij, welke in Indië daartoe de gelegenheid hebben, door hunne onderzoekingen trachten de zaak verder tot klaarheid te brengen. Wellicht dat er bij meer volken, evenals bij de hierboven genoemde, analoge sporen zijn aan te wijzen van de gewoonte om de tanden te vijlen als teeken van rouw.

De tandvijling als teeken van rouw zou, volgens Dr. Uhle, geheel beantwoorden aan de in Polynesië, onder anderen op Hawai en Tonga, bestaande gewoonte bij sterfgevallen, eveneens als rouwbedrijf, een of meer tanden uit te breken ${ }^{25}$, "denn der Unterschied der Deformationsformen ist in dem Falle von minderer Bedeutung, als der gemeinsame Charakter, dass Deformation zur Trauer geschieht" (blz. 7). Ook de tandvijling bij de puberteit, resp. het huwelijk, heeft een dergelijken tegenhanger. In Australië en in enkele streken van Melanesië bestaat namelijk het gebruik om knapen, zoodra zij manbaar zijn geworden, een tand uit te slaan 26. Merkwaardig nu is het, dat dit gebruik in den Indischen Archipel eveneens voorkomt. "Bei malaiischen Völkern", aldus Uhle (blz. 5), "findet sich nicht nur die Sitte, die Zähne, im Alter der Pubertät, zu feilen, sondern zunächst auch die, Zähne im Alter der Pubertät auszubrechen. Von zwei Stellen des Gebietes dieser Völker ist sie zur Zeit bestätigt. Herr Riedel theilte in einem Aufsatze über die bisher noch fast unbekannten Stämme von Central Celebes (Bijdragen tot de T. L. en Vk. van Nederl. Indië, 5e volgreeks, dl. I, blz. 92) mit, dass bei den Tonapo, Tobada und Tokulabi, Stämmen dieses Gebietes, mannbaren Mädchen die zwei oberen Vorderzähne ausgeschlagen werden, und zwar geschehe dies, wie sie sagen, quod mulier quondam mariti membrum virile momordit. Andererseits wird von zwei verschiedenen Seiten das Vorkommen der Sitte des Zähneausbrechens im Pubertätsalter von Formosa bestätigt. Herr Joest berichtete (Verhandl. der berl. Ges. f. Anthr., 1882, S. 58) dass

2s Zie hierover onder anderen: Von Ihering, Die künstliche Deformirung der Zähne, blz. 255.

26 Von Ihering, 0. c., blz. 256 vv. 
Mädchen auf Formosa im Alter der Pubertät die beiden oberen Schneidezähne eingeschlagen werden, "I/damit sie besser athmen könnten, und mehr Wind (= Seele, Belebung?) in sie hineinkäme "" , und Aehnliches (Ausschlagen eines Zahnes im Pubertätsalter) berichtete von daselbst Herr Pauli für Knaben (Mittheil. Geogr. Ges. Lübeck, 1883, S. 75)" - - Het is aan Dr. Uhle ontgaan, dat nog van een ander eiland in den Indischen Archipel dit gebruik door verschillende berichtgevers geconstateerd wordt. Op Enggano namelijk pleegt men aan de vrouw bij het huwelijk de beide hoektanden uit te stooten, "opdat een ieder zien kunne dat zij niet meer vrij, maar het eigendom van een ander is" $\mathbf{2 7}$.

Uit het aangevoerde blijkt dus dat de tandvijling parallel gaat met het gebruik van het uitbreken der tanden. Het is de verdienste van Dr. Uhle dit duidelijk te hebben doen uitkomen, aangetoond te hebben dat die twee zaken niet tegengesteld, doch identiek zijn. "Die Zahnfeilung zur Trauer", aldus luidt (blz. 17) zijne conclusie, waarmede wij ons vrij wel vereenigen kunnen, "ist die gemilderte Form des Ausbrechens der Zähne zur Trauer. Ebenso muss die Zahnfeilung im Pubertätsalter die gemilderte Form des Ausbrechens der Zähne im Pubertätsalter sein. Die rohere Form des Ausbrechens der Zähne muss allenthalben der gemilderten Form des Zahnfeilens vorausgegangen sein" .

Voor de vraag naar de oorspronkelijke beteekenis van de tandvijling is deze conclusie, dat tandvijling en tanduitbreking identiek zijn, van groot gewicht. Te reeht komt onzes inziens Dr. Uhle

97 Van der Straaten en Severijn, Verslag van een in 1854 bewerkstelligd onderzoek op het eiland Engano, Tijdschr. v. Ind. T. L. en Vk., dl. III, blz. 361. Zie ook : Walland, Het eiland Engano, Tijdschr. v. Ind. T. L. en Vk., dl. XIV, blz. 104, en Verslag van eene reis van den Assistent Resident van Bengkoelen naar Engano, Tijdschr. v. Ind. T. L. en Vk., dl. XIX, blz. 193. Volgens het bericht van Walland heeft het uitstooten der hoektanden plaats vóor het huwelijk, ten bewijze dat het meisje manbaar is. - Evenzoo wordt, in de kort geleden gepubliceerde verhandeling van den Heer Helfrich over het eiland Enggano (Tijdschr. v. h. Nederl. Aardr. Genootsch., 2e serie, dl. V, bl. 272 vv.), van dit uitbreken der tanden gewag gemaakt, dat volgens dezen schrijver ook gebeurt, zoodra de meisjes den huwbaren leeftijd hebben bereikt. Tegenwoordig heeft dit echter weinig meer plaats (Helfrich, O. c., blz. 298 en 307, aanteekening 24. Zie ook blz. 286, waar de legende omtrent den oorsprong van deze gewoonte wordt medegedeeld. De Engganeezen zouden namelijk afstammen van eenen Chinees, die bij eene zeug kinderen verwekte. Daar het dier zich aanvankelijk tegen de copulatie verzette en den Chinees verwondde, sloeg deze het met een hakmes de slagtanden uit. Het uitbreken der hoektanden an de meisjes zou in navolging hiervan ontstaan zijn) 
(blz. 16) op tegen de meening van Von Ihering, die "als Grundzweck der im Pubertätsalter vorgenommenen Zahnfeilung die Absicht den Körper zu verschönern" wil aannemen. Zeker is het dat bij de meeste volken van den Indischen Archipel het vijlen der tanden tegenwoordig werkelijk met dit doel geschiedt. Doch dit mag geen reden zijn, om daarin den oorsprong van het gebruik te zoeken. Zeer juist merkt Uhle (blz. 13-14) op "dass bei Erklärung von Volkssitten die für den Forscher zunächstliegende nicht auch immer die richtigste ist, dass für ein Volk eine Sitte, durch welche es seinen Körper verändert, gleichviel welchen Umständen die Sitte entsprungen ist, für eine ästhetische zu halten immer am nüchsten liegt, schliesslich, dass die allgemeinen Beziehungen speciell an der Zahnfeilung, welche alle bei der Berechnung des ursprünglichen Zwecks in 's Gewicht fallen können, so viele, die Vorstellungen der Malaien über den eigentlichen Zweck der Sitte aus so vielen mannigfaltig und z. T. wunderbar verbundenen Factoren zusammengesetzt sind, dass man nicht gerade ein besonderes Recht hat, ein einzelnes, übrigens sehr äusserliches Motiv, wie das ästhetische, einfach aus der Reihe der übrigen herauszugreifen und es zum historischen Kopfe für alle übrigen jetzt wirkenden Motive zu setzen". Uit het feit dat de tandvijling bij het intreden der puberteit in den Indischen Archipel slechts een verzwakte vorm is van het gebruik van het uitbreken der tanden op hetzelfde tijdstip, zooals het zich nu nog in Australië en enkele streken van Melanesië voordoet, volgt vanzelf dat zij oorspronkelijk dezelfde bedoeling moet hebben gehad als dit laatste. Welke nu is deze bedoeling? "Der australische Gebrauch", aldus luidt het antwoord van Dr. Uhle op deze vraag (blz. 17), "Knaben im Pubertätsalter Zähne auszubrechen, reiht sich einer grösseren Zahl australischer Gebräuche ein, deren gemeinsamer äusserer Charakter und wesentlicher Grundzug der ist, Knaben den Eintritt in das mit dem Vollmass menschlicher Rechte ausgestattete Alter der Erwachsenen zu erschweren" 28. Evenzoo beschouwt hij met Ploss 29, "als wesentliche Eigenthümlichkeit vieler das Pubertätsalter der Mädchen begleitenden Gebräuche diejenige, dass sie Peinigungen sind, welche gewissermassen die Standhaftigkeit des armen Wesens

28 Vergelijk hierover: Bastian, Zur naturwissenschaftlichen Behandlungsweise der Psychologie, blz. 130, waarheen ook Uhle verwijst.

20. Ploss, Das Weib in der Natur- und Völkerkunde, dl. I, blz. 160 (blz. 243 van den 2en druk). 
prüfen" (t. a. p.). "Man hat also ein Recht", aldus besluit hij, "auch in den verbreiteten Sitten, mannbaren Knaben und Mädchen im Pubertätsalter Zähne auszuschlagen, dem Zwecke der Kasteiung dienende Gebräuche zu sehen". Vanzelf moet dit dan ook, blijkens het zooeven opgemerkte, de oorspronkelijke bedoeling van de tandvijling zijn geweest. "Die unmittelbare Beziehung der malaiischen Pubertätszahnfeilung zur Kasteiungssitte, im Pubertätsalter Zähne auszubrechen", voert volgens Dr. Uhle (blz. 17) er toe "auch die malaiische Zahnfeilung im Pubertätsalter als einen ursprünglichen Kasteiungsgebrauch erscheinen zu lassen". Wij willen deze conclusie niet bestrijden, doch vragen slechts: Behoort het gebruik om bij sterfgevallen, als teeken van rouw, de tanden uit te breken, resp. te vijlen, op dezelfde wijze verklaard te worden? En zoo ja, is deze zelfpijniging, deze zelfkastijding van den aanvang af het eenige doel van de tandenmutilatie geweest? Het blijkt niet wat de meening van Dr. Uhle, vooral omtrent dit laatste, is. Laat mij daarom op eenige feiten de aandacht vestigen, die waarschijnlijk dienen kunnen, om het vraagstuk nader tot zijne oplossing te brengen.

Het uitbreken der tanden, resp. de meer verzachte vorm daarvan, de tandvijling, komt als rouwgebruik niet alléén voor, doch gaat dikwijls gepaard met andere zelfverminkingen. Zoo verwondt men zichzelven, snijdt zich de haren of een lichaamsdeel, een vingerlid bij voorbeeld, af, enz. Deze zelfverminkingen in den rouw moeten, zooals ik dit elders uitvoerig heb trachten aan te toonen ${ }^{\mathbf{3 0}}$, oorspronkelijk even zoovele offerhandelingen zijn geweest, waarvan zij dan ook nog dikwijls het karakter vertoonen. Het uit de toegebrachte wonden vloeiende bloed wordt onder anderen wel eens aan den doode gegeven, gelijk, om hiervan een enkel voorbeeld, bepaaldelijk uit den Indischen Archipel, aan te voeren, dit het geval is bij de Orang-Sakei, die in Siak de bovenstreken van de Mandau bewonen ${ }^{31}$.

so Zie mijne verhandeling: Ueber das Haaropfer und einige andere Trauergebräuche bei den Völkern Indonesiens, blz. 57 vv. (van den overdruk).

$31 \mathrm{Bij}$ sterfgevallen plegen namelijk de nabestaanden zich met een mes, boven op het hoofd, overdwars eene snede toe te brengen, zoodat bloed er uitvloeit, dat dan aan den overledene gegeven wordt, door het op zijn aangezicht te laten druppelen (Van Rijn van Alkemade, Het rijk Gassip, Tijdschr. v. h. Aardr. Gen. , 2e serie , dl. II, blz. 239. Zie ook: Hijmans van Anrooy, Siak Sri Indrapoera, Tijdschr. v. Ind. T. L. en Vk., dl. XXX, blz. 349). - Meerdere voorbeelden, waaruit blijken kan hoezeer de zelfverminkingen in den rouw dikwijls het karakter hebben van eene offerhandeling, vindt men in mijne in de voorgaande noot geciteerde verhandeling, blz. $66-67$. 
Ook de afgesneden haren worden vaak werkelijk ten offer gebracht. Zoo deden de oude Arabieren ${ }^{32}$ en de Grieken. Men herinnert zich de vermelding van deze gewoonte in den Tlias, onder anderen bij de beschrijving van den uitvaart van Patroklos:

„Vooraan gingen de rijders, gevolgd door een wolke van voetvolk,

Duizenden; voorts in hun midden Patroklos gedragen door makkers,

Welke den doode bestrooiden met haar van hun lokken gesneden".

Evenzoo sneed Achilleus, toen men op de plek was gekomen, waar de verbranding van het lijk zou plaats hebben, het haar van zijnen schedel en legde het zijnen makker in handen ${ }^{33}$. Ook bij een paar volken van het Maleisch-Polynesische ras komt dit haaroffer aan afgestorvenen voor. De Palau-eilanders knipten zich baard en haren af en legden die, ter eere van den overledene, op het lijk ${ }^{34}$. Op Babar, een van de Zuidwester-eilanden, bestaat het gebruik, dat bij eene begrafenis de bewoners der huizen, waarlangs de doode gedragen wordt, een weinig van hun haar afsnijden en naar buiten werpen ${ }^{35}$, terwijl bij de Alfoeren van het district Tonsawang in de Minahasa de naaste bloedverwanten gewoon zijn, eene lok van hunnen schedel te nemen en die in de zoogenaamde walosong - eene op het graf ten behoeve van den afgestorvene geplaatste miniatuur-woning op te hangen 36. Gelijk men weet, is dit offeren van bloed en haren slechts eene toepassing van het beginsel "pars pro toto", het geven van een deel van het lichaam voor het geheele lichaam ${ }^{36 a}$. De onderstelling dat de mutilatie der tanden bij sterfgevallen op dezelfde wijze, zoo nu niet meer, dan toch oorspronkelijk eene offerhandeling is geweest, ligt voor de hand.

Vele van de zooeven bedoelde practijken, die bij eene begrafenis plaats hebben, komen ook voor bij het intreden der puberteit. Zoo, om ons alleen hiertoe te bepalen, de afsnijding der haren. In de

32 Voorbeelden hiervan vindt men bij Goldziher, Le culte des ancêtres et le culte des morts chez les Arabes, blz. 20, en Le sacrifice de la chevelure chez les Arabes, Revue de l'histoire des religions, dl. XIV, ilz. 49 vlg.

ss Ilias, XXIII, 134 vv. - Zoo offerde Hekuba, volgens Ovidius (Metamorph., XIII, 426-427), op het graf van Hektor, met hare tranen, ook hare grijze haren.

34 Waitz, Anthropologie der Naturvölker, dl. V, blz. 153.

35 Riedel, De sluik- en kroesharige rassen tusschen Selebes en Papua, blz. 362.

36 Meerdere voorbeelden, waaruit blijken kan hoezeer de in den rouw afgesneden haren dikwijls werkelijk ten offer gebracht worden, vindt men in mijne verhandeling: Ueber das Haaropfer und einige andere Trauergebräuche bei den Völkern Indonesiens, blz. 63-65.

36a Zie uitvoeriger hierover mijne in de voorgaande noot geciteerde verhandeling, blz. $68-71$. 
eerste levensjaren is het kind niet alleen aan tal van werkelijke, doch ook aan verschillende vermeende gevaren blootgesteld. Booze geesten en daemonen belagen het, en niets natuurlijker dus dan dat men het door hen begeerde leven tracht te behouden door het haar, dat immers in de plaats van het geheele lichaam kan worden gegeven, ten offer te brengen. Vandaar het haaroffer bij de geboorte, dat echter ook dikwijls uitgesteld wordt tot het tijdstip van het afsluiten der kinderjaren, bij het intreden der puberteit of het huwelijk ${ }^{37}$. Op die wijze kan ook de tandenmutilatie in dezelfde gevallen verklaard worden. Van de oude Peruanen vinden wij dan ook een bericht, waaruit blijkt, dat deze handeling bij hen werkelijk het karakter van een offer bezat. "The people of Guancavilcas", aldus lezen wij, "pulled out three teeth from each jaw of their young children,

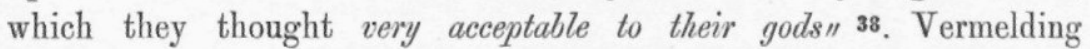
verdient nog hetgeen ons van een der stammen van Nieuw-Holland medegedeeld wordt. De leden van dien stam gelooven aan een boozen geest, "der die Eingeborenen nur dann nicht verschlingt, wenn sie ihm zeigen, dass ihnen ein Zahn ausgeschlagen ist" 38a. Hier geschiedt dus het tanduitbreken nog met het bepaalde doel, om het door den daemon begeerde leven te behouden, is het nog duidelijk eene offerhandeling krachtens het beginsel "pars pro toto".

Het uitbreken van een of meer tanden, resp. de tandvijling, bij het intreden der puberteit of bij het huwelijk moet oorspronkelijk eene offerhandeling zijn geweest. Deze godsdienstige beteekenis kan dan in latere jaren verloren zijn gegaan en voor eene politieke of sociale hebben plaats gemaakt 39 . Ook hier hebben wij op eene analogie bij de haarsnijding te wijzen. De plechtige haarsnijding toch is dikwijls het symbool van onderwerping en algeheele overgave 39a. Krijgsgevangenen, die in slavernij weggevoerd worden,

37 Zie dit uitvoerig aangetoond en met voorbeelder toegelicht in mijne meer aangehaalde verhandeling: Ueber das Haaropfer und einige andere Trauergebräuche bei den Völkern Indonesiens, blz. 90 vv.

38 Spencer, Principles of sociology, blz. 291.

$3 s_{\mathrm{a}}$ Waitz, Anthropologie der Naturvölker, dl. VI, blz. 787.

39 Zoo kan dan ook de tandenmutilatie bij het intreden der puberteit, naarmate hare beteekenis van offerhandeling op den achtergrond trad, langzamerhand het karakter verkregen hebben van een "Kasteiungsgebrauch", gelijk door Dr. Uhle bedoeld wordt.

soa Hoe dit begrip zich ontwikkeld heeft uit de haarsnijding als offerhandeling heb ik trachten aan te toonen in mijne verhandeling: Ueber das Haaropfer und einige andere Trauergebräuche bei den Völkern Indonesiens, blz. 107 vv. 
pleegt men wel eens het hoofd kaal te scheren ${ }^{40}$. Ook het afsnijden van het haar bij het huwelijk, vooral waar het alleen bịj vrouwen plaats heeft, is niet zelden een teeken van onderwerping aan het gezag van den man ${ }^{41}$. Dat de mutilatie der tanden in enkele gevallen evenzeer dit karakter bezit, kan uit het hierboven medegedeelde omtrent de bewoners van Enggano gebleken zijn. Merkwaardig is overigens hetgeen wij van eenige der wilde stammen van Centraal-Amerika vermeld vinden, dat zij namelijk gewoon zijn, aan krijgsgevangenen een voortand weg te nemen, blijkbaar om hen als dediticii te kenmerken ${ }^{42}$. Zoo ook lezen wij van de bewoners van Oostelijk Nieuw-Holland: "Der Stamm der Camera-gal.... steht in anerkannter Superiorität über den andern Stämmen, als deren Auerkennungszeichen er einen Zahn von den jungen Leuten der anderen Stämme fordert" $\mathbf{4 3}$.

In het voorgaande hebben wij getracht, den oorsprong van de mutilatie der tanden, vooral naar analogie der ritueele haarsnijding, te verklaren 43a. Intusschen zijn wij de eersten om te erkennen, dat de zaak nog verre van bewezen is. Het was ons dan ook, gelijk wij begonnen zijn op te merken, alleen te doen om enkele feiten aan te geven, die tot eene oplossing der quaestie voeren kunnen.

Het werk van Dr. Uhle kan gezegd worden, ten naasten bij alles te bevatten wat over de tandvijling bij de volken van den Indischen Archipel is op te merken, en dus eene vrij volledige mono-

40 Zoo bij de oude Arabieren. "Dem Gefangenen, den man laufen lässt, schneidet man zuvor die Stirnholle ab, und behält sie zum Zeichen, dass man ihn in der Gewalt gehabt hat" (Wellhausen, Reste arabischen Heidentumes, blz. 118). Zie ook mijne in de voorgaande noot geciteerde verhandeling, blz. 110-111, en verder blz. 114 vv., waar men nog andere voorbeelden van haarsnijding als symbool van overgave en onderwerping vinden kan.

41 Voorbeelden hiervan vindt men in mijne verhandeling over het haroffer, blz. 116 vv.

42 Bancroft, The native races of the Pacific States of North America, dl. I, blz. 764.

43 Waitz, Anthropologie der Naturvölker, dl. VI, blz. 786.

43a Nog op andere punten openbaart zich eene merkwaardige overeenkomst tusschen de rol, die de haren, en die, welke de tanden, in het godsdienstig en maatsohappelijk leven, vervullen. Zoo is de haarsnijding bij vele volken eene straf (Zie hierover mijne verhandeling: Ueber das Haaropfer und einige andere Trauergebräuche bei den Völkern Indonesiens, blz. 122-123). Wanneer wij nu lezen, dat, bij eenige der bergstammen van Dekkan, aan personen, die van tooverij worden beschuldigd, de voortanden uitgestooten worden (Kohler, Indische Gewohnheitsrechte, Zeitschrift für vergleichende Rechtswissenschaft, dl. VIII, blz. 146 en 147), dan is dit ook zeker als eene straf te beschouwen. Zoo komt ook het gebruik voor, om bij de 
graphie over dit onderwerp te zijn. Daarom is het te betreuren, dat hij twee zaken, die daarmede ten nauwste samenhangen, het zwartmaken der tanden en het versieren der tanden met goud, onvermeld gelaten heeft. Kortelijk wenschen wij nog bij deze twee practijken hier stil te staan.

Op het vijlen der tanden volgt gewoonlijk, als noodzakelijk aanhangsel, het zwart-maken. Men bezigt hiervoor eene soort van vernis, bij de Maleiers en Bataks badja geheeten, die op verschillende wijzen verkregen wordt. $\mathrm{Bij}$ de Maleiers van Midden-Sumatra en van den Riouw-Lingga Archipel vervaardigt men de badja door een stuk karamunting-hout (Rhodomyrtus tomentosa Dc.) of ook een stuk van de harde schaal eener kokosnoot te verbranden, waarbij er een vocht uitdruipt, dat in een ijzeren lepel wordt opgevangen en waaraan verschillende bestanddeelen toegevoegd worden. In enkele streken van de Padangsche Bovenlanden wordt de badja gemaakt door het genoemde hout te verbranden onder eenen klapperdop, waarin een gat is gemakt en waarboven de ijzeren lepel gehouden wordt. De walm, die tegen den lepel aanslaat, geeft roet, dat met olie en andere ingredienten wordt vermengd ${ }^{44}$. Ook de Bataks en de Dajaks van de Zuidooster-Afdeeling van Borneo en van Sarawak verkrijgen de kleurstof, waarmede de tanden zwart-gemaakt worden, op ongeveer dezelfde wijze 45. Anders gaan de Javanen te werk bij het kleuren

haren te zweren (Zie mijne zooeven aangehaalde verhandeling, blz. 106, noot 215). Een voorbeeld om dit bij de tanden te doen, vinden wij bij de wilde stammen van Centraal-Amerika (Bancroft, The native races of the Pacific States of North America, dl. I, blz. 771).

44 Van Hasselt, Volksbeschrijving van Midden-Sumatra, blz. 8; Von de Wall-Vau der Tuuk, Maleisch woordenboek, i. v. gĕrang. - Met badja schijnt in den Riouw-Lingga Archipel een ander tandzwartsel te worden aangeduid, "een toebereidsel van metaal, vermoedelijk met spiesglans vermengd" (Von de Wall-Van der Tuuk, i. v. badja).

45 Neumann, Het Pane- en Bila-stroomgebied, Tijdschr. v. h. Nederl. Aardr. Gen., 2e serie, dl. III, blz. 463, noot; Hagen, Die künstlichen Verunstaltungen des Körpers bei den Batta, Zeitschrift für Ethnologie, jaarg. 1884 (dl. XVI), blz. 220-221 ; Perelaer, Ethnographische beschrijving der Dajaks, blz. 99; Grabowsky, Das Feilen und Färben der Zähne bei den Bewohnern Südost-Borneos, Ausland, jaarg. 1884, blz. 126; Hardeland, Dajaksch woordenboek, i. v. katiting; Boyle, Adventures among the Dyaks of Borneo, blz. 227-228. - Door de tanden met dit vernis te besmeren, aldus merkt Grabowsky (t. a. p.) op, "ersetzt man unbewusst die durch die Feilung verlorene feste Zahnsubstanz und verhütet das schnelle Verderben der Zühne, welches sonst durch die scharfen Ingredienzien des Sirihkauens sicher schnell erfolgen würde". Ook Hagen teekent aan dat het taaie vernis, niet alleen de tanden duurzaam zwart kleurt, doch "zugleich eine etwa 
hunner tanden. Daartoe bezigen zij de zoogenaamde banjon, eene mondspoeling bestaande uit klapperwater, waarin men een stukje gloeiend ijzer gedompeld heeft en het daarin eenige dagen heeft laten staan. Sommigen kauwen nog op de schil van eenen granatappel alvorens de banjon te appliceeren ${ }^{46}$. Van een dergelijk middel bedienen zich ook de Makassaren en Boegineezen. Dit middel, bij de eerstgenoemden babanju geheeten, bestaat, volgens Dr. Matthes, uit de schil van eenen granaatappel, stinkend klapperwater (misschien op dezelfde wijze verkregen als bij de Javanen) en padakkí of koperroest. Meestal wordt de granaatappelschil afzonderlijk in den mond gestoken en gekauwd. Daarbij neemt men van tijd tot tijd eene pen, met katoen omwonden en met het klapperwater bevochtigd, tusschen de tanden, en wrijft dezen, zoo dikwijls men met de operatie ophoudt, met een pruimpje tabak, dat in de padakki gedoopt is 47 .

Het zwart-maken der tanden na de vijling, hoewel zeer verbreid in den Archipel, komt bij enkele volken niet voor. Zoo onder anderen bij de Mentawei-eilanders, wier tanden als blinkend wit beschreven worden ${ }^{48}$. Ook de Timoreezen kleuren de tanden niet, hoewel zij dezen, gelijk wij boven gezien hebben, wel vijlen. Integendeel worden zij gezegd veel moeite te doen, "om hunne witte

eröffnete Zahnhöhle verstopft" (blz. 221). Evenzoo zegt Van Hasselt (blz. 8) dat, volgens den Maleier, door de bestrijking met de badja ude blootliggende zenuwen gedood worden.", terwijl Hardeland opmerkt, dat de katiting, het tandzwartsel, "auch gegen Zahnschmerz gut sein soll". Het besmeren met het vernis schijnt dus heilzaam te werken op de, door de vijling van het glazuursel beroofde, tanden. Toch zijn wij het met Grabowsky niet eens, waar hij meent, dat hierin de oorsprong van het zwart-maken van het gebit moet worden gezocht. De vraag blijft dan, hoe andere volken, welke zich niet van zulk een vernis bedienen, gelijk, zooals wij dadelijk in den tekst zullen zien, de Javanen, Makassaren en Boegineezen, tot het gebruik gekomen zijn. Bovendien zijn er (zie beneden blz. 492-493), zoowel in als buiten den Archipel, tal van stammen, die alleen de tanden kleuren, zonder ze vooraf te vijlen, en van wie het niet behoeft te worden aangenomen, dat zij voorheen de vijling gekend, doch die later prijsgegeven hebben. Vergelijk ook noot 63a beneden.

46 Poensen, Iets over de kleeding der Javanen, en Kreemer, Hoe de Javanen hunne tanden verzorgen, Mededeelingen v. w. h. Nederl. Zend. Gen., dl. XX, blz. 292-293, en XXV, blz. 200; Tjondro Negoro, Aanteekeningen op het eerste deel van Veth's Java, blz. 19; Roorda-Vreede, Javaansch Woordenboek, i. v. banju.

${ }^{47}$ Matthes, Makassaarsch woordenboek, i. v. babanju, en Boegineesch woordenboek, i. v. djidji.

${ }^{48}$ Von Rosenberg, De Mentawei-eilanden, en Hinlopen en Severijn, Verslag van een onderzoek der Poggi-eilanden, Tijdschr. v. Ind. T. L. en Vk., dl, I., blz. 410, en dl. III, blz. 324 . 
tanden te reinigen en in orde te houden" ${ }^{49}$. Hetzelfde vinden wịj ook van de Amboneezen, Christenen en Mohammedanen, vermeld 50. En dat dit niet een uitvloeisel is van den omgang met Europeanen, blijkt voldoende uit een bericht van Valentijn. "Hoewel ", zegt hij, "'er onder deze inlanders ook zyn, die pek-swarte glimmende tanden (in navolging der Maccassaaren) voor een groot cieraad houden", zijn bij hen "witte en zuivre tanden zeer gemeen, veragtende vele Europeers, die geele of blaeu-begroeide tanden hebben, een zaak, waarin zy ons buiten alle tegenspraak overtreffen " 51 . Gelijk men de tanden wel eens vijlt, zonder ze zwart te maken, komt het omgekeerde, het zwart-maken der tanden zonder voorafgaande vijling, ook voor. Buiten den Indischen Archipel treft men dit gebruik aan bij een paar Amerikaansche volken 52 en bij de Japaneezen 53, verder bij de bewoners van de Palau-eilanden en de Marianen ${ }^{54}$. Ook bij de Kambodjers heeft er bij de plechtigheid der huwelijksvoltrekking eene ceremonie plaats, waarbij bruidegom en bruid naast elkander geplaatst worden en de bonzen bij hen

${ }^{49}$ Bijdragen tot de kennis van het eiland Timor en Onderhoorigheden, Tijdschr. v. Nederl. Indië, jaarg. 1849 , dl. II, blz. 314. - Zoo zegt ook de Heer Riedel in zijne beschrijving van de Timoreezen: "Mund und Zähne werden sehr rein gehalten, die letzteren werden, wie bei den Somali im östlichen Afrika, fortwährend mit einem Stücke weichen Holzes geputzt" (Riedel, Die Landschaft Dawan oder West-Timor, Deutsche geographische Blätter, dl. X, blz. 229). Vergelijk ook de hierbeneden blz. 501 in den tekst geciteerde mededeeling van den Heer Heymering.

so Van Hoëvell, Ambon en de Oeliasers, blz. 33. - Ook Dr. Riedel spreekt van het vijlen, niet van het zwart-maken der tanden bij de Amboneezen (Riedel, De sluik- en kroesharige rassen tusschen Selebes en Papua, blz. 75-76).

${ }^{51}$ Valentijn, dl. II, blz. 165. - Het is eene verkeerde voorstelling (zie onder anderen noot 11a hierboven) dat de tanden zwart worden door het betelkauwen. De betel of sirih, zegt de Heer Van Hasselt, kleurt tandvleesch, tong en lippen hard steenrood, maar heeft geen invloed op het gebit (Van Hasselt, Volksbeschrijving van Midden-Sumatra, blz. 6-7). Dat de tanden, zelfs als zij gevijld zijn, bij eenige zorg ook wit blijven, in weerwil van het gebruik van den betel, blijkt uit het medegedeelde in den tekst omtrent de Timoreezen en de Amboneezen (De Mentawei-eilanders kunnen hier niet genoemd worden daar zij geen sirih kauwen). Zoo zegt ook Marsden, na over het zwart-maken der tanden te hebben gesproken: "When this (het zwartsel) is not applied, the filing does not, by destroying what we term the enamel, diminish the whiteness of the teeth ; but the use of betel renders them black, if pains be not taken to prevent it" (Marsden, History of Sumatra, blz. 53).

52 Bancroft, The native races of the Pacific States of North America, dl. II, blz. 371 en 372 .

5s Zie: Von Thering, Die künstliche Deformirung der Zähne, blz. 254-255, en de daar angehaalde brounen.

54 Von Ihering, O. e., blz. 255-256. 
hunne gebeden komen opzeggen, "waarna de bestrijking (niet de afvijling) der tanden van de bruid met een zeker vernis plaats heeft 55 . Zoo worden ook de Anamitische vrouwen gezegd jong er goed uit te zien, doch na het huwelijk spoedig oud en leelijk te worden, waartoe het zwart-maken der tanden (van vijling wordt er niet gesproken) het zijne bijdraagt 56. Van de Indonesische volken noemen wij in de eerste plaats de bewoners van Bontok, een landschap in Noord-Luçon. "Die verheiratheten Weiber", aldus lezen wij van hen, "färben sich die Zähne schwarz; zu diesem Zweck brennen sie ein harzreiches Holz und verreiben den sich bildenden Russ vermittelst Zuckerrohrsaft auf einem flachen Steine. Um das Färben der Zähne zu bewerkstelligen, werden dieselben abgetrocknet, einige Zeit mit einem Lappen gerieben und die Farbe mit basi- (wein-) befeuchteten Fingern von dem Steine abgerieben and auf die Zähne aufgetragen". Hetzelfde wordt ons ook van de bewoners van het, in de nabijheid van Bontok gelegen, landschap Guinân medegedeeld 57. Verder verdienen nog de Soloreezen hier vermeld te worden. Algemeen is bij hen het kleuren der tanden in gebruik, terwijl nitdrukkelijk vermeld wordt, dat niet allen de tanden daarbij vijlen ${ }^{57 a}$.

Met een enkel woord dient hier nog het zwart-maken van het

55 Wiselius, De Franschen in Indo-China, blz. 213.

56 Wiselius, O. c., blz. 95. - Het kan zijn dat de Kambodjers en de Anamiten voorheen de tandvijling hebben gehad, doch dat zij die later prijsgegeven en alleen het zwart-maken behouden hebben. Hetgeen hiervoor zou kunnen pleiten, is het feit dat de vijling heden ten dage nog in Achter-Indië voorkomt, onder anderen bij de Siameezen (Uhle, blz. 4) en eenige der wilde stammen, de Banars en de Sedangs, die langs de Mekong wonen (Uhle, t. a. p.; Von Ihering, blz. 254). Ook de meer oorspronkelijke vorm van de tandenmutilatie, het uitbreken, wordt hier aangetroffen, en wel bij de Penongs of Piaks, die meer Zuidelijk langs de genoemde rivier, ten Oosten van het meer Tonle Sap, verblijf houden. Deze Penongs of Piaks breken zich de voortanden uit om niet, zooals zij zeggen, op de apen te gelijken (Wiselius, De Franschen in Indo-China, blz. 183). Verder moeten de Miao-tse hier genoemd worden, die in de bergachtige streken van Zuid-China gevestigd zijn, doch met andere Achter-Indische stammen, onder anderen de Siameezen, verwant zijn, met dezen althans gerekend worden tot dezelfde volkenfamilie, die der Thai, te behooren. Van een dezer Miao-tse stammen, de Ta-jaki-lao, lezen wij, dat zij aan hunne vrouwen bij het huwelijk twee tanden plegen uit te slaan (Uhle, t. a. p.).

57 Schadenberg, Beiträge zur Kenntniss der Banao-Leute und der Guinanen, en Beiträge zur Kenntniss der im Innern Nord-Luzons lebenden. Stämme, Verhandlungen der Berliner Gesellschaft für Anthropologie, Ethnologie und Urgeschichte, 1887, blz. 149 , en 1888 , blz. 36 .

57a Bijdragen tot de kennis van het eiland Timor en Onderhoorigheden, Tijdschr.

v. Nederl. Indië, jaarg. 1849, dl. II, blz. 309.

5e Volgr. III. 
gebit bij de reliefvijling te worden besproken. Deze soort van vijling komt hoofdzakelijk op Java voor. Het schijnt nu dat de banjon, de mondspoeling die de Javanen gebruiken, de tanden alleen kleurt, als het glazuursel daarvan geheel verwijderd is. Bij de reliefvijling, wanneer men het voorvlak der tanden zoodanig bewerkt, dat het glazuursel niet overal weggenomen wordt, doch een gedeelte daarvan overblijft, zal men dus het resultaat bereiken, dat dit gedeelte zich wit op een zwarten grond verheft. Zoo bij voorbeeld bij de reliefvijling met spitsvijling hierboven (blz. 475) bedoeld. Het is dan ook bepaaldelijk wegens zijne overeenkomst, niet alleen in gedaante, doch ook in kleur met een komkommerpit, dat het, door het overgebleven glazuursel gevormde, relief bij deze vijling met den naam van widji-timun bestempeld wordt 57b. Degenen, aldus vinden wij nog vermeld, die hunne tanden op deze wijze laten bewerken, zijn meestal jongelieden, die, wanneer zij den ouderdom van veertig jaren hebben bereikt, tot het effen zwart overgaan, door het relief weg te nemen ${ }^{\mathbf{5 7}}$.

Het zwart-maken der tanden bij de volken van den Indischen Archipel geschiedt tegenwoordig alleen dewijl men zwarte tanden mooi vindt. De dandy, zegt de Heer Van Hasselt, die met een bestudeerden glimlach zijne lippen optrekt om de hagelwitte tanden te laten zien, zou bij de Maleische schoonen zijn doel ten eenenmale missen en haar waarschijnlijk den uitroep ontlokken : săroman andjïng, "precies een hond" 58. Hetzelfde geldt vas de Javanen en van andere volken van den Archipel. "Hare tanden", aldus luidt in den wajang Palasara de beschrijving van eene Javaansche Venus, "zijn zwart gelijk de vleugels van een hommel en schitteren ver-

57b Tjondro Negoro, Aanteekeningen op het eerste deel van Veth's Java, blz. 19. Uit deze plaats blijkt ook, dat de bewerking der tanden op de wijze widji-timun niet altijd met spitsvijling gepaard gaat. Soms blijft de onderkant der tanden recht, terwijl het ruit- of, volgens den Javaan, komkommerpit-vormig relief zich in het midden van het voorvlak der tanden voordoet.

57e Tjondro Negoro, t. a. p. - Het feit dat bij de reliefvijling een gedeelte der tanden wit blijft, heeft waarschijnlijk den Heer Kreemer tot de minder juistei voorstelling geleid, dat bij de vijlingen, die hij widji-kraï en ngĕlar-djontrô noemt, het zwart-maken niet geschiedt (Kreemer, Hoe de Javanen hunne tanden verzorgen, Mededeel. v. w. h. Ned. Zend. Gen., dl. XXV, blz. 204). Hoewel hij het niet zegt, zijn toch deze twee vijlingen blijkbaar reliefvijlingen, overeenkomende, wat althans de eerstgenoemde betreft, met de vijling widji-timun, gelijk uit den naam reeds blijken kan, daar vidji-kraï ook "komkommerpit" beteekent (De kraï is eene soort van komkommer).

68 Van Hasselt, Volksbeschrijving van Midden-Sumatra, blz. 6. 
blindend; indien zij glimlachte, geleken zij druppelend verdikt suikersap" 59. - Van beteekenis is het, dat in de oudere literarische producten, in de oud-Javaansche dichtwerken, omgekeerd witte tanden als het schoonste sieraad worden geprezen. Zoo heet het in het Smaradahana, bij gelegenheid dat eene schoone beschreven wordt, onder anderen van haar: "Pinghe ning wadja kesisan lați katon kadi salaga kinĕmbangan mirah", dat is: het wit harer tanden, welke de (geopende) lippen blootlieten, leek een kelk met bloembladen van robijn ${ }^{\circ}$. Het zou verkeerd zijn hieruit de conclusie te trekken - hoewel die oogenschijnlijk voor de hand ligt - dat, tijdens de dichter dit schreef, het zwart-maken der tanden nog niet bestond. Het woord wadja toch, dat in de aangehaalde zinsnede voorkomt in den zin van "tand", pleit eerder voor het tegendeel. Immers, dit woord beteekent eigenlijk - zooals wij boven gezien hebben - het zwartsel waarmede de tanden gekleurd worden, en kan eerst later eene benaming zijn geworden voor de zwart-gemaakte tanden-zelve, daarna voor tanden in het algemeen ${ }^{6}{ }^{\mathrm{a}}$. Dat het

${ }^{59}$ Ook in den wajang Pandu komt eene dergelijke beschrijving van eene Javaansche schoone voor: "De uitdrukking van haar gelaat was aangenaam, bevallig en schrander, hare wangen geleken partjes-doerian, hare lippen ingesneden manggistan, hare tanden druppels water, zij glansden gelijk de vleugels van een hommel" (Van der Vliet, De wajang Pandu, Bijdragen tot de T. L. en Vk. v. Nederl. Indië, 4e volgr., dl. III, blz. 284. Zie ook noot 2 van de aangehaalde bladzijde).

${ }^{60} \mathrm{Kern}$, Mengelingen, Bijdragen tot de T. L. en Vk. v. Nederl. Indië, 4e volgr., dl. I, blz. 148-149.

60a Behalve in het Javaansch, komt wadja, onder den vorm van bödjöh en vazana, respectievelijk in het Madoereesch en in het Malagasisch als benaming van tand, in de laatstgenoemde taal speciaal van kies, voor. - Eene dergelijke verschuiving van beteekenis is, zooals Dr. Van der Tuuk dit met tal van voorbeelden heeft aangetoond (Het Lampongsch en zijne tongvallen, Tijdschrift v. Ind. T. L. en Vk., dl. XVIII, blz. 148 vlg.), niet zeldzaam. Zoo vinden wij het woord sijung, in het Javaansch "slagtand" (van een dier), doch ook "hoektand" of "oogtand" (van een mensch), onder den vorm sihung, in het Lampongseh terug in de beteekenis van "tandzwartsel". Verder wijzen wij op pinggang (Javaansch), penggang (Bataksch), gordel = pinggang (Maleisch), heup; kuluk (Javaansch), tëngkuluk (Maleisch), takuluk (Bataksch), tangkolok (Tagalsch), eene soort van muts of hoed = takolok (Dajaksch), hoofd ; subang (Maleisch), suwěng (Javaansch), sibong (Bataksch), sowang (Dajaksch), enz., eene soort van oorversiersel = suwong (Sangareesch), oor; daun (Maleisch), daon (Javaansch), raung (Makassaarsch), daung (Boegineesch), enz., blad = daon (Bataksch), geneesmiddel; wwad (oud-Javaansch), wod (Javaansch), wortel = obat (Maleisch), geneesmiddel, enz. Over het algemeen kan het gezegd worden, dat, in deze en soortgelijke gevallen, de meest verbreide beteekenis de oorspronkelijke, de minst voorkomende dasrentegen de secundaire, door verschuiving ontstane, is. Zoo - moeten subang, suw èng, enz., primitief wel "oorversiersel", en niet "oor", kuluk, těngkuluk, enz., "hoofddeksel", en niet "hoofd", hebben be- 
zwart-maken der tanden toen dus reeds plaats had, lijdt geen twijfel, doch blijkbaar minder als een maatregel tot verfraaiing, daar anders onze dichter witte tanden niet zoo zou hebben geprezen, dan wel als eene verplichting bij, of kort vóór, het huwelijk. Evenals nu nog, gelijk zooeven is opgemerkt, de Timoreezen en Amboneezen witte tanden hoog achten, moeten de Javanen dit ook voorheen gedaan hebben.

Uit het laatst medegedeelde blijkt dus dat eertijds de Javanen, terwijl zij de tanden reeds zwart plachten te maken, witte tanden op prijs stelden. Een middel tot verfraaiing was dus primitief het

duid. Van wadja of badja nu hebben wij in den tekst aangenomen, dat de beteekenis van tandzwartsel de oorspronkelijke is, en het woord eerst later in gebruik gekomen is voor de zwart-gemaakte tanden-zelve, daarna voor de tanden in het algemeen. Dit vereischt nog eenige toelichting. Het woord wadja of badja komt in tal van talen voor, ook in het Oosten, onder anderen in het Alfoerseh van de Minahasa onder den vorm van uaja of uvaja, in de beteekenis van "staal". Nu geloof ik dat dit badja $=$ staal (hetzij het woord oorspronkelijk Maleisch-Polynesisch is, hetzij aan het Sanskrit ontleend) identiek is met badja = tandzwartsel. Dat men het tandzwartsel met het woord voor "staal" heeft benoemd, is waarschijnlijk daaraan toe te schrijven, dat bij de bereiding daarvan, gelijk wij gezien hebben, steeds ijzer of het een of ander ijzeren voorwerp gebezigd wordt, niet alleen bij de Javanen, doch ook bij de Maleiers, Bataks en Dajaks. Bij de laatstgenoemde volken toch bestaat het tandzwartsel hoofdzakelijk uit een vocht, dat door verbranding van bepaalde houtsoorten of van de harde schalen eener kokosnoot wordt verkregen, welk vocht echter altijd op ijzer (een ijzeren lepel, een mes of iets dergelijks) moet worden opgevangen (Zie hierboven blz. 490 en de in noot 45 aangehaalde bronnen). Misschien dat men dus ijzer als een onmisbaar bestanddeel van het zwartsel heeft beschouwd, en op die wijze er toe gekomen is, dit laatste daarnaar te benoemen. De aanwending van het woord badja = staal, in plaats van den gewonen term voor "ijzer", is dan verder gemakkelijk te verklaren. Het begrip toch, wat staal is, is zelfs heden ten dage bij den inlander van den Archipel nog vrij onbepaald, zoodat met dezen nam ook vaak het smeedijzer wordt aangeduid *). De Alfoer van de Minahasa bij voorbeeld beschouwt ijzeren braadpannen als staal en gebruikt ze als zoodanig. Zoozeer is dit het geval, dat het woord romping of rumping = braadpan bij hen zelfs geheel de beteekenis verkregen heeft van staal (Zie: Mededeelingen omtrent de Alfoersche taal van Noordoost-Celebes, Vergelijkende woordenlijst, Bijdragen tot de T. L. en Vk. van Nederl. Indië, 3 e volgreeks, dl. V, blz. 90-91). Op die wijze kan dus het woord badja eene benaming zijn geworden voor tandzwartsel, en later op de tanden zijn overgedragen.

*) Dit is volkomen verklaarbaar. Gelijk men toch weet, berust het onderscheid tusschen smeedijzer en staal op het versehil in koolstofgehalte, dat bij het eerste $\frac{1}{2}$ tot $\frac{2}{3}$, bij het laatste $\frac{3}{4}$ tot 2 perc. bedraagt. Smeedijzer gaat dus bij veel koclstof langzaam in staal over, zoodat het verschil tusschen de twee niet altijd, althans voor den inlander, even duidelijk kan zijn. 
zwart-maken niet ${ }^{61}$. Hoe is dan het gebruik ontstaan? Uitgaande van de boven gegeven verklaring omtrent den oorsprong der tandvijling, wil ik trachten, een antwoord op deze vraag te geven. Meer dan eene gissing is echter hetgeen hier zal worden aangevoerd niet.

Het vijlen der tanden is, gelijk werd opgemerkt, slechts een verzachte vorm van het uitbreken der tanden. Het spreekt nu vanzelf, dat waar dit laatste nog als eene sociale of religieuze verplichting bestond, men, bij het niet-nakomen daarvan, getracht zal hebben de tanden, die uitgebroken hadden behooren te worden, zooveel mogelijk aan het oog te onttrekken, onkenbaar te maken. En zeker kon dit niet beter geschieden, dan door ze met eene donkere kleur te bedekken en zoo humne schittering te doen ophouden, dus $\min$ of meer den indruk te geven, dat daar ter plaatse zich geene tanden meer bevonden. Ook hier hebben wij op eene analogie bij de ritueele haarsnijding te wijzen. Zooeven spraken wij van het gebruik, om bij de plechtigheid van de huwelijksvoltrekking aan de bruid de haren af te snijden. Langzamerhand is men echter bij enkele volken er toe gekomen, dit geheel na te laten of slechts eene lok weg te nemen, doch is aan de vrouwen de verplichting opgelegd, om de haren na het huwelijk, niet meer, gelijk vóór dien tijd, los te laten hangen, doch opgestoken of opgebonden te dragen en ze zelfs met een doek te bedekken ${ }^{62}$. Hetgeen men had behooren te verwijderen, moest dus ook hier zooveel mogelijk verborgen worden. Overigens is het duidelijk dat de behoefte om de tanden zwart, dat is onkenbaar, te maken, te vermommen, zich bijzonder zal hebben doen gevoelen daar, waar het tanduitbreken nog eene religieuze verplichting, eene offerhandeling was, gelijk bij

61 En hiermede zou vanzelf de verklaring moeten vervallen, door Prof. Veth van het gebruik gegeven. "Daar door het vijlen", zoo lezen wij (Java, dl. I, blz. 609), "het verglasel der tanden weggenomen en derhalve hun zwart worden bevorderd wordt, sehijnt deze gewoonte aanleiding te hebben gegeven, dat de inlanders van witte tanden allengs een afkeer kregen, zoodat men zich zelfs van kunstmiddelen bedient, om de afgevijlde tanden ten spoedigste de zwarte kleur to doen aannemen". Men vergelijke bovendien noot 51 , waaruit blijkt dat het zwartworden der tanden niet zoo noodwendig een gevolg van het vijlen behoeft te zijn. Overigens geldt ook hier het opgemerkte aan het slot van noot 45 , dat er namelijk volken zijn, die alleen de tanden kleuren, zonder ze vooraf te vijlen, en van wie het niet noodig is aan te nemen, dat rij deze laatste bewerking voorheen gekend, doch die later prijsgegeven hebben.

62 Voorbeelden hiervan vindt men in mijne verhandeling: Ueber das Haaropfer und einige andere Trauergebräuche bei den Völkerù Indonesiens, blz. 117 vv. 
sterfgevallen. Want hier gold het vooral geen aanstoot te geven aan de geesten der afgestorvenen, door hun herhaaldelijk te vertoonen hetgeen men hun onrechtmatig onthouden had. Dergelijke beschouwingen liggen, gelijk wij dit elders uitvoerig hebben aangetoond, aan meerdere rouwgebruiken ten grondslag. Met bijna alle heeft men toch oorspronkelijk ten doel gehad, zich van de vervolgingen van de geesten der afgestorvenen te vrijwaren, aan welke vervolgingen men zich blootgesteld achtte, zoolang men aan die geesten nog niet had gegeven waarop zij aanspraak hadden. Zoo kwam men er ook bij voorbeeld toe, alle sieraden af te leggen of die, welke men niet van het lichaam verwijderen kon, met lappen te omwikkelen, ten einde ze niet aan de geesten te vertoonen ${ }^{63}$. Ook hierin vinden wij dus eene nadere bevestiging voor de gissing, dat met het zwart-maken der tanden primitief slechts eene vermomming bedoeld werd $\mathbf{6 3}^{\mathrm{a}}$.

In de tweede plaats wenschen wij nog te spreken over het versieren der tanden met goud. In oude reisverhalen vinden wij reeds van dit gebruik gewag gemaakt. Zoo lezen wij, in het "Journaal gehouden op het schip Hollandia door den adelborst Frank van der Does" (2 April 1595-13 Juni 1597) 64, van de bewoners van Sumatra, dat zij, "seer leelycke swarte gesleepen tanden hebben ende sommighe die haeren mondt versiert es met silvere ende goude tanden die syluyden uyttrecken ende weeder in steecken cunnen ", terwijl het iets verder van de Javanen heet, dat zij "middelmatige

os Zie hiervoor mijne in de voorgaande noot geciteerde verhandeling, blz. 17 vv. en 51 . 63a Hierboven hebben wij gezien hoe er volken zijn, die de tanden zwart-maken zonder ze vooraf te vijlen. Het kan zijn, gelijk wij dit in noot 56 speciaal van de Kambodjers en de Anamiten opmerkten, dat zij voorheen de vijling gekend, doch die later prijsgegeven hebben. Uit het hier in den tekst aangevoerde volgt eohter vanzelf, dat zij ook zeer gued rechtstreeks tot het gebruik kunnen zijn gekomen om de tanden zwart te maken, zonder voorafgaande vijling. - Overigens is het duidelijk, dat primitief alleen die tanden gekleurd, dat is vermomd, werden, welke uitgebroken hadden moeten worden, dat is bij vele volken, zooals onder anderen bij de Engganeezen (zie hierboven blz. 484), de hoektanden. Bij de verschuiving van beteekenis, waarover in noot 60a gehandeld is, moet dus aanvankelijk het woord voor tandzwartsel eene benaming zijn geworden voor die tanden alleen. Zoo laat het zich dan ook vorklaren dat sihung, in het Lampongsch, "tandzwartsel", en, onder den vorm sijung, in het Javaansch, "hoektand" beteekent. Natuurlijk kan echter ook het omgekeerde gebeurd zijn, sihung of sijung oorspronkelijk "hoektand" hebben beduid en eerst later eene benaming zijn geworden voor datgene, waarmede bij voorkeur die tand besmeerd werd, het tandzwartsel.

${ }^{64}$ Opgenomen in het werk van De Jonge, De opkomst van het Nederlandsch gezag in Oost-Indië, dl. II, blz. 287 vv. 
parsoonen syn.... met geheel swart leelycke zwarte ende gebrooken tanden, soedat er veel syn die silvere ende goude tanden in haeren mond hebben, deselve cunnen sy uyt ende insetten" 65. Verder treffen wij bij Valentijn een bericht aan omtrent de Makassaren. "Een van de grootste cieraaden stellen zy in hunne tanden te slypen, die git swart te houden, of die zoo te maken, en zommige trekken 'er goude kassen, na de tanden gemaakt, over heenen, dat voornamelyk een cieraad der groote vrouwen hier is " 66. Eindelijk nog moet er op gewezen worden, hoe, in de hiervoren reeds genoemde beschrijving van de Philippijnen door een Spaansch geestelijke van het begin der 17e eeuw, opgenomen in het bekende werk van Thévenot "Relations de divers voyages cvrievx ", van het versieren der tanden met goud bij de bewoners dier eilandengroep, bepaaldelijk misschien bij de Tagala's en Bisaya's, gesproken wordt. Na de vijling vermeld te hebben, merkt de schrijver op, dat genoemde inlanders hunne tanden bedekken "d'vn vernis noir et lustré, ou de couleur de feu, et ainsi leurs dents deuiennent noires on rouges comme du vermillon; et dans le rang d'en-haut, ils font vne petite ouuerture qu'ils remplissent d'or, qui brille d'auantage sur le fond noir ou rouge de ces vernis" $\mathbf{6 7}$.

Heden ten dage wordt het gebruik om de tanden met goud te versieren, onder al de genoemde volken, nog alleen bij de Sumatranen aangetroffen $\mathbf{6 8}$. Allereerst komen de Bataks in aanmerking.

65 De Jonge, O. c., blz. 324 en 333. - Uit de geciteerde woorden zou men kunnen opmaken, dat de Javanen en Sumatranen gouden en zilveren tanden in den mond hadden, in den zin van onze kunsttanden. Blijkbaar hebben de gouden of zilveren plaatjes, waarmede de tanden belegd of bekleed werden, dien indruk op den schrijver gemaakt, en hebben wij hier dus alleen aan eene minder juiste beschrijving, ten gevolge van gebrekkige waarneming, te denken.

66 Valentijn, dl. III, 2, blz. 137. Zie ook: dl. II, blz. 165-166.

o7 Thévenot, O. c., dl. II, blz. 4.

os Van de Tagala's en Bisaya's wordt het gebruik niet meer vermeld. Evenmin makt Dr. Matthes, in zijne zoo uitvoerige mededeelingen over de Makassaren en Boegineezen, ergens gewag van deze gewoonte. Hetgeen dan ook in het opstel "Ueber Zähne und Zahnhandel", Ausland, jaarg. 1871, blz. 595, zonder bronnenopgave , gezegd wordt, dat "die Macassaren bisweilen zwei Vorderzähne ausziehen, um deren Stelle mit Zähnen reinen Goldes oder Silbers zu ersetzen", verdient zonder meer, als onjuist, ter zijde gesteld te worden. Wat de Javanen zoowel van Middenals Oost-Java betreft, uitdrukkelijk wordt van hen verklaard, dat zij de gewoonte heden ten dage niet meer hebben (Tjondro Negoro, Aanteekeningen op het eerste deel van Veth's Java, blz. 19 en 24). Daarom kunnen wij alleen onder reserve hier overnemen hetgeen de Heer Kreemer zegt, dat er namelijk zijn, "die de beide voortanden masr weinig laten afzagen, om ze dan geel te maken of in goud 
Volgens Dr. Van der Tuuk heet odang-odang bij hen "eene strook messing of goud, die. men op de boventanden zóó hecht, dat het onderste en bovenste gedeelte der tanden zichtbaar is " 69. Uitvoeriger is Dr. Hagen in zijne beschrijving van dit sieraad der Bataks. "Ist Jemand ganz besonders reich und eitel, so lässt er sich seine Zähne mit Goldblech beschlagen. Ein schmales, 1-2 mm. breites Streifchen dieses Metalles wird nahe dem Kaurande quer über die oberen Schneidezähne gelegt und an den Enden mit zwei kleinen Nägeln an dén beiden äusseren Schneide- oder Eckzähnen befestigt. Die Goldbleche selbst haben mancherlei Form, von dem eben erwähnten schmalen Streiflein bis zur breiten, auch den Kaurand bedeckenden und nach der Hinterfläche übergreifenden Lamelle, in welcher die Zähne wie in einer Scheide stecken. In seltenen Fällen ist das Goldblech ornamentirt oder ihm ein einfaches Ornament aus Kupfer oder Soassa (Legirung von Kupfer und Gold) aufgelöthet" 70. Verder moeten de Maleiers van Midden-Sumatra genoemd worden. Ongeveer een jaar of langer na het vijlen, worden de tanden met goud versierd. Daartoe boort de goudsmid er gaatjes in en maakt het belegsel gereed, dat dan aan en in de tanden wordt bevestigd $\mathbf{7 1}$. Ook Marsden makt uitvoerig van dit gebruik gewag. "The great men", aldus lezen wij bij hem, "sometimes set their teeth in gold, by casing, with a plate of that metal, the under row; and this ormament, contrasted with the black dye, has, by lamp or candle light, a very splendid effect. It is sometimes indented to the shape of the teeth, but more usually quite plain. They do not remove it either to eat or sleep " $\mathbf{7 2}$.

Behalve bij de Bataks en Maleiers van Sumatra treft men deze wijze, om de tanden te versieren, heden ten dage nog aan bij de Dajaks van Sarawak, de Igorroten van de Philippijnen, de bewoners van Leti-Moa-Lakor in de Molukken en bij de Timoreezen. "I found",

te vatten", hetgeen, zooals de schrijver er bij voegt, "onder de grooten in de vorstenlanden meermalen moet plaats hebben" (Kreemer, Hoe de Javanen hunne anden verzorgen, Mededeelingen v. w. h. Nederl. Zend. Gen., dl. XXV, blz. 200). Dit bericht verdient zeker eene nadere bevestiging.

69 Van der Tuuk, Bataksch woordenboek, i. v. odang.

70 Hagen, Die künstlichen Verunstaltungen des Körpers bei den Batta, Zeitschrift für Ethnologie, jaarg. 1884 (dl. XVI), blz. 221. Zie ook van denzelfden schrijver: Eine Reise nach dem Tobah-See in Zentralsumatra, Petermanns Mittheilungen, jaarg. 1883, blz. 46.

71 Van Hasselt, Volksbeschrijving van Midden-Sumatra, blz. 8.

72 Marsden, History of Sumatra, blz. 53. 
aldus vertelt onder anderen Hornaday in eene beschrijiving van de Zee-Dajaks, die langs de Simoejan, een rechtertak van de Sadong, wonen, "that each upper incisor and canine tooth was capped by a smooth plate of copper, held in place by a pin driven into a hole in the tooth " 73, terwijl Blumentritt van de Igorroten zegt, dat bij de voornamen onder hen het gebruik bestaat, dat "die Zähne mit einem breiten Goldblech bedeckt werden " ${ }^{\mathbf{7 3}}$ a. Wat de bewoners van LetiMoa-Lakor betreft, zijn het volgens den Heer Riedel de marna's, personen van adel, die de twee voorste tanden met goud plegen te beleggen 74 . Ook bij de Timoreezen is het gebruik beperkt tot de aanzienlijken, vooral tot de meo's of voorvechters. Dezen hebben de boven- en de ondertanden met gouden plaatjes bekleed, die bij het spreken schitterend te voorschijn komen. Ieder dezer plaatjes, zegt de Heer Heymering, " bedekt nagenoeg twee halve tanden en is door een schroefje tusschen de voegen derzelve bevestigd. Het is alleen de weerkaatsing van het goud tegen de witte tanden, waarvan het middelste gedeelte bloot blijft (want de Timoreezen zijn, ofschoon anders niet zeer proper op hun lijf, op hunne tanden zeer zindelijk) die sommigen doet meenen dat elke tand geheel met goud overtrokken is " 75. Uitvoerig spreekt ook de Fransche reiziger De Freycinet over de gewoonte der aanzienlijjken bij de Timoreezen "de revêtir une ou plusieurs de leurs dents incisives d'une lame d'argent ou d'or ". "Déjà Péron ", aldus gaat hij voort, "l'avoit remarquée; mais n'ayant pu découvrir par quel procédé le métal étoit plaqué, il crut qu'un mastic particulier, dont il regrettoit de n'avoir pu connoître la composition, servoit à l'assujettir sur l'émail même de la dent. D'après M. Gaimard, tout le secret se borne à percer la dent et le métal, et à fixer celui-ci avec de petites goupilles de la même matière, dont on rive les pointes par derrière. M. Duperrey, sans s'appuyer sur aucune observation qui lui soit propre, révoque en doute la perforation de la dent, et pense qu'on peut obtenir plus simplement le même résultat, en introduisant les goupilles entre cette dent et les deux latérales" $\mathbf{7 6}$.

73 Hornaday, Two years in the jungle, blz. 393.

73a Blumentritt, Ethnographie der Philippinen, blz. 25.

74 Riedel, De sluik- en kroesharige rassen tusschen Selebes en Papua, blz. 371-372.

75 Heymering, Een inlandsche oorlog op het eiland Timor, Tijdschr. v. Nederl. Indië, jaarg. 1846, dl. III, blz. 210-211.

76 De Freycinet, Voyage autour du monde, 1817-1820, dl. I, blz. 625-626. Zie ook: Péron, Voyage de découvertes aux terres australes, 1800-1804, di. I, blz. $160-161$. 
Dat deze meening van Duperrey de juiste is, blijkt uit de mededeeling van Heymering, waarin ook niet van eene doorboring der tanden gesproken wordt $\mathbf{7 7}$.

Eene eenigszins andere versiering van het gebit ontmoet men bij de Olo-Ngadju's van de Zuidooster-Afdeeling van Borneo. Hierboven zagen wij hoe volgens den Spaanschen geestelijke uit het begin der 17e eeuw, die eene beschrijving gegeven heeft van de Philippijnen, bij de bewoners dezer eilandengroep de gewoonte bestond, niet om de tanden met gouden plaatjes te bekleeden, maar om er gaatjes in te boren en die met goud te vullen. Iets dergelijks nu doen heden ten dage de Olo-Ngadju's. Dezen dragen namelijk gouden stiftjes tusschen de tanden, welke stiftjes, tatek geheeten, volgens den Heer. Perelaer, er uitzien als spijkertjes met twee koppen. Het kopje, dat tusschen de lippen zichtbaar is, heeft een omtrek van ongeveer drie strepen en gewoonlijk eene zesvlakkige piramidale gedaante met zwakke hellingen. Het naar de achterzijde van den mond gekeerde kopje heeft eene bolronde gedaante 7s. De Heer Grabowsky zegt echter, dat de tatek "ein ganz kunstloser kleiner Stift aus Gold oder einer Mischung von Messing und Kupfer" is 79. Deze tatek's worden gedragen tusschen de oog- en de eerste snijtanden, aan weerszijde van den mond. Bij enkele individuen ziet men zulke stiftjes tusschen al de snijtanden der bovenkaak, zoodat wanneer zij de lippen openen, zij eene rij sterretjes laten zien, die des te meer afsteken en glinsteren, omdat zij, door het verwen der tanden, zich op een gitzwarten achtergrond voordoen en daarbij goed onderhouden en blinkend gepoetst worden ${ }^{\mathbf{8}}$. Niet altijd echter komen

77 Hogendorp (Beschrijving van het eiland Timor, Verhandelingen v. h. Bat. Gen. v. K. en W., dl. I, blz. 207) en Sal. Müller (Reizen in den Indischen Archipel, dl. II, blz. 237) spreken ook van het gebruik der Timoreesche voorvechters en grooten om de tanden met dunne plaatjes goud te beleggen, zonder echter de wijze te vermelden waarop dezen bevestigd worden. - Over hetgeen Dr. Riedel ter zake mededeelt, zie noot 82 hierbeneden.

78 Perelaer, Ethnographische beschrijving der Dajaks, blz. 99.

79 Grabowsky, Das Feilen und Färben der Zähne bei den Bewohnern SüdostBorneos, Ausland, jaarg. 1884, blz. 126. "Was Herr Perelaer über die Form der Goldstifte sagt", merkt Grabowsky verder op, "würde sehr für die damaligen dajakischen Goldkünstler sprechen ..... Ich habe leider versäumt, mir die Köpfchen so genau anzusehen, aber nach anderen in meinem Besitz befindlichen Goldarbeiten der Dajaken zu schliessen halte ich die heutigen Goldschmiede der Dajaken überhaupt nicht für fähig, einem $2 \mathrm{~mm}$. (leze: $3 \mathrm{~mm}$.) grossen Köpfehen eine sechseckige pyramidale Gestalt mit schwachem Neigungswinkel zu geben".

80 Perelaer, t. a. p. 
de stiftjes aan de tanden van de bovenkaak voor, doch ook wel aan die van de onderkaak, zooals door Grabowsky geobserveerd werd. Bovendien zegt deze, dat die stiftjes niet tusschen de tanden, doch in gaatjes, opzettelijk in de tauden geboord, gedragen worden ${ }^{81}$.

Deze wijze om de tanden te versieren, schijnt heden ten dage alleen tot de Dajaks beperkt te zijn ${ }^{82}$. Echter treft men bij de Bataks iets aan dat eenigermate daarmede vergeleken kan worden.

${ }^{81}$ Grabowsky, t. a. p. - De laatste mededeeling van Grabowsky komt overeen met hetgeen wij bij Von Thering (Die künstliche Deformirung der Zähne, blz. 251) vermeld vinden. "Іи hohem Grade bemerkenswerth", aldus lezen wij daar, "ist das, was J. B. Davis (Thesaurus craniorum, p. 289) von Dajak-Schädeln beschreibt. Unter seinen Dajak-Schädeln sind einige, an denen die oberen Schneidezähne gefeilt sind. An dem fünften der Sammlung ist an der Vorderfläche aller Vorderzähne durch den Schmelz eine Durchbohrung gemacht, ein Loch, welches mit Betel gefüllt ist. Bei dem Schädel Nr. 279, der p. 290 abgebildet ist, sind die sämmtlichen Vorderzähne an ihren Rändern beträchtlich abgefeilt. Sodann ist an den oberen Schneide- und Eckzähnen auf ihrer Vorderfläche je ein Canal dureh den Schmelz in die Zahnhöhle getrieben, und in dieses Loch ist je ein kleiner gelber Nagel von Messing (brass) getrieben, der einen runden Kopf besitzt, welcher auf der Vorderfläche des Zahnes festsitzt".'

82 Hetgeen Dr. Riedel van de Timoreezen zegt, zou doen denken dat bij hen het gebruik bestond. "Die Vorderzähne der Vornehmen", aldus lezen wij, "werden gebohrt und mit Gold und Silber ausgefullt" (Riedel, Die Landschaft Dawan oder West-Timor, Deutsche geographische Blätter, dl. X, blz. 284). Al de schrijvers over Timor, hierboven in den tekst en in noot 77 geciteerd, maken echter van deze wijze van versiering geen gewag, doch spreken alleen van het bekleeden of beleggen der tanden met plaatjes goud. Misschien heeft Dr. Riedel zich hier vergist. In allen gevalle verdient zijn bericht eene nadere bevestiging. - Verder zou volgens Von Ihering het gebruik, om in de tanden gaatjes te boren en die met goud of eenig metaal te vullen, bij de Makassaren bestaan. Intusschen berust zijne mededeeling op het enkele feit, dat van den schedel van een Makassaar, aanwezig in eene collectie te St. Petersburg, aan de beide middelste tanden en evenzoo aan den uitersten linker snijtand van de bovenkaak, "auf der Vorderfläche sich je ein Loch befindet, welches durch Betel schwarz ist" (Von Ihering, Die künstliche Deformirung der Zähne, blz. 252). Op grond hiervan te concludeeren dat de Makassaren algemeen hunne tanden op dezelfde wijze versieren als de Dajaks tegenwoordig en de bewoners van de Philippijnen voorheen (Von Ihering, O. c., blz. 260), is zeker meer dan gewaagd, afgescheiden daarvan dat het bij de onzekerheid, die er vaak omtrent de herkomst van de schedels uit den Indischen Archipel bestat (zie hierover: Meyer, Einige Bemerkungen über den Werth, welcher im Allgemeinen den Angaben in Betreff der Herkunft menschlicher Schädel aus dem ostindischen Archipel beizumessen ist, Mittheilungen der anthropologischen Gesellschaft in Wien, dl. IV), het zeer de vraag is of men hier werkelijk met een exemplaar van Makassar te doen heeft. Voor ons is het overigens een voldoend bewijs dat het gebruik niet op Zuid-Celebes bestaat, dat Dr. Matthes, de grondige kenner van de zeden en gebruiken der Makassaren en Boegineezen, er met geen enkel woord in zijne geschriften over spreekt. 
Wij laten hier het desbetreffende bericht van Dr. Hagen volgen. "Abergläubische vornehme Leute", schrijft deze na over de belegging der tanden met goud te hebben gesproken, "lassen sich überdies noch vom guru (Zauberdoctor) in ihre Zahnstümpfe, meist die unteren Eckzähne, selten die oberen, kleine dreieckige Löcher meisseln, die mit der Basis gegen den Schneiderand, mit der Spitze gegen das Zahnfleisch gerichtet sind, und welche vom guru mit einem kräftigen obat (Medizin) gefüllt und mit einem, genau in das Loch passenden, dreieckigen Perlmutterblättchen geschlossen werden. Ausnahmsweise trägt man diese Perlmutterblättchen auch in runden Löchern in Mitte der grossen oberen Schneidezähne. Hat das betreffende Individuum Siri gekaut, was beim Batta den ganzen Tag hindurch geschieht, so erhält das Perlmutterblättchen durch den rothen Sirispeichel einen goldigen Glanz und kann Unerfahrenen selbst für Gold imponiren. Die vom guru in den Zahn verschlossene Medizin hat die hochgeschätzte Eigenschaft, alles Gift, welches etwa

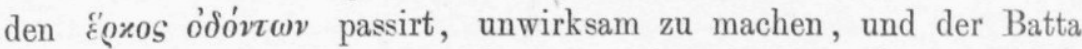
fühlt sich im Besitz dieser Medizin so sicher, dass er selbst einen von seinem ärgsten Feind ihm angebotenen Siri unbedenklich annehmen würde, obwohl dies die gewöhnlichste Art der Beibringung von Gift sein soll" 83 .

En hiermede nemen wij afscheid van het werk van Dr. Uhle. Het aangevoerde kan voldoende zijn om te doen zien, hoe verdienstelijk hij zich weder daarmede voor de ethnologie van den Indischen Archipel gemaakt heeft. Voorzeker zou het de grootste belooning voor zijne moeite zijn, zoo door zijnen arbeid zij, welke in Indië daartoe in de gelegenheid zijn, opgewekt worden om in de aangegeven richting onderzoekingen in te stellen, opdat zoo het ontbrekende of minder goed bekende aangevuld, het onjuiste verbeterd worde. Voor mij, met deze verklaring wensch ik te eindigen, is het bestudeeren van het werk van Dr. Uhle eene aangename en leerrijke taak geweest. Dit opstel moge den schrijver dan ook een bewijs zijn, hoezeer $\mathrm{ik}$, in weerwil van de gemaakte opmerkingen en bedenkingen, het groote gewicht erken van de resultaten waartoe hij gekomen is.

Leiden, April 1888.

ss Hagen, Die künstlichen Verunstaltungen des Körpers bei den Batta, Zeitschrift für Ethnologie, jaarg. 1884 (dl. XVI), blz. 221. 